\title{
Completely discontinuous organic/ inorganic hybrid nanocomposites by self-curing of nanobuilding blocks constructed from reactions of $\left[\mathrm{HMe}_{2} \mathrm{SiOSiO}_{1.5}\right]_{8}$ with vinylcyclohexene
}

\author{
Norihiro Takamura, Lisa Viculis, Chunxin Zhang and Richard M Laine* \\ Departments of Materials Science and Engineering, Chemistry, and the Macromolecular Science and Engineering Center, University of \\ Michigan, Ann Arbor, MI 48109-2136, USA
}

\begin{abstract}
The reaction of 4-vinyl-1-cylcohexene with $\left[\mathrm{HMe}_{2} \mathrm{SiOSiO}_{1.5}\right]_{8}$ provides tetra- and octa-2cyclohexenylethyloctasilsesquioxanes. The tetrabifunctional [cyclohexenylethylMe $\left.\mathrm{SiOSiO}_{1.5}\right]_{4}-\left[\mathrm{HMe}_{2} \mathrm{SiOSiO}_{1.5}\right]_{4}$ (average degree of functionalization) melts near $80^{\circ} \mathrm{C}$ and can be cast and then cured (by thermal hydrosilylation) into transparent nanocomposite shapes. These materials, while not nanoporous, offer dielectric constants of 2.8-2.9 at $100 \mathrm{kHz}$ to $3 \mathrm{MHz}$, and are air stable to temperatures $\geq 400^{\circ} \mathrm{C}$. The resulting materials appear (by $\mathrm{X}-$ ray diffraction) to be partially ordered after curing. The octafunctional material also melts at low temperatures (ca $120^{\circ} \mathrm{C}$ ) and can be copolymerized with hydridosiloxanes to give similar materials with lower thermal stability. The synthesis and characterization of the starting materials is described, as well as thermal curing studies and properties characterization of the resultant nanocomposites.
\end{abstract}

(c) 2007 Society of Chemical Industry

Keywords: self-curing; bifunctional; silsesquioxanes; oxidation resistance; transparent

\section{INTRODUCTION}

We and others have undertaken extensive studies designed to develop routes to organic/inorganic hybrid nanocomposites using nanobuilding blocks based on the cubic silsesquioxanes $\left[\mathrm{HMe}_{2} \mathrm{SiOSiO}_{1.5}\right]_{8}$, (OHS) and functionalized octaphenyloctasilsesquioxanes $\left[\mathrm{RPhSiO}_{1.5}\right]_{8}\left(\mathrm{R}=\mathrm{NH}_{2}, \mathrm{Br}\right.$, I, etc. $)$, both of which are easily prepared from low-cost starting materials. ${ }^{1-35}$ In these systems, the core consists of the smallest single crystal of silica $(0.5 \mathrm{~nm}$ in diameter) that acts as a rigid, hard particle functionalized at each of eight vertices. The core also provides the heat capacity of silica introducing a robustness not normally found in organic compounds. The functionalization can be used to form organic links or tethers between vertices.

Each functional group occupies one octant in Cartesian space, hence these cage or cubic systems are perfect nanobuilding blocks for constructing nanocomposites with excellent control of uniformity from nanometer to centimeter length scales. ${ }^{31-35}$

The types of tethers and the reaction chemistry used to connect vertices provide access to hybrid materials wherein the periodicity within the nanocomposite, the coupling of the organic phase to the inorganic phase and to itself can be very well defined

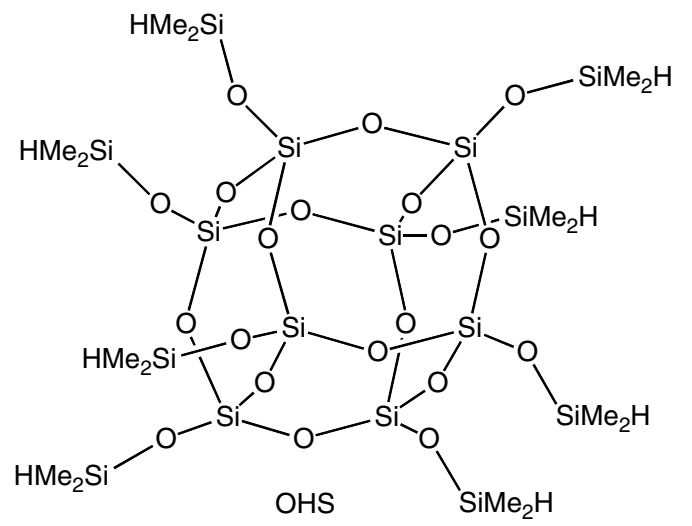

and tailored. ${ }^{31,32}$ If the rigid core is considered to be a constant, then systematic changes in the nanoarchitecture of the organic components can be used to develop structure-processing-property relationships that allow correlations to be drawn between nanostructure and the macroscopic or global properties of these materials.

Because these nanocomposites closely resemble the 'interphase' materials that form at interfaces in macroscopic organic/inorganic composites, ${ }^{36-39}$ they may offer information on property transfer (mechanical, photonic, electronic) across these interfaces, a process

* Correspondence to: Richard M Laine, Departments of Materials Science and Engineering, Chemistry, and the Macromolecular Science and Engineering Center, University of Michigan, Ann Arbor, MI 48109-2136, USA

E-mail: talsdad@umich.edu 
thought to be critical to developing optimal composite materials. Because they resemble interphase rather than bulk phase materials, they also offer the opportunity to create materials that have properties nonlinearly related to bulk phase properties. The potential exists to create whole new classes of materials.

In the majority of our studies to date, we sought crosslinking chemistry that leads to hybrid nanocomposites wherein single organic tethers connect two cube vertices only. ${ }^{31-34}$ That is, the organic phase interacts with the inorganic phase and vice versa with no chemical bonds forming between tethers. These completely discontinuous nanocomposites allow us to examine the influence of mechanical load transmission across interfaces at the nanoscale rather than through an organic matrix, which would result if the organic tethers were to copolymerize. Furthermore, the tethers used in our studies are typically $1-3 \mathrm{~nm}$ in length, such that in most instances, the organic component can be thought to represent a single segment in a wholly organic polymer. This has implications for understanding the behavior of single segments decoupled from polymer chains.

We have demonstrated the success of this approach for sets of epoxy resin nanocomposites. ${ }^{31-35} \mathrm{We}$ and others have described extensions to polyimide nanocomposites. ${ }^{28,29,40,41}$ However, we return here to our oldest systems wherein simple hydrocarbon units couple cube vertices. These early systems provide the basis for extending the above concepts to systems with more flexible hydrocarbon units.

In our original studies, we systematically characterized products from hydrosilylative crosslinking of $\left[\mathrm{HSiO}_{1.5}\right]_{8}$ and $\left[\mathrm{HMe}_{2} \mathrm{SiOSiO}_{1.5}\right]_{8}$ with $\left[\mathrm{CH}_{2}=\mathrm{CHMe}_{2} \mathrm{SiOSiO}_{1.5}\right]_{8}$ and $\left[\mathrm{CH}_{2}=\mathrm{CHSiO}_{1.5}\right]_{8}$ giving simple $\mathrm{CH}_{2} \mathrm{CH}_{2}$ tethers. ${ }^{42}$ The resulting porous materials offered surface areas of $400-600 \mathrm{~m}^{2} \mathrm{~g}^{-1}$ and pore volumes typically $<0.4 \mathrm{mLg}^{-1}$. The shortest tethers, formed between $\left[\mathrm{HSiO}_{1.5}\right]_{8}$ and $\left[\mathrm{CH}_{2}=\mathrm{CHSiO}_{1.5}\right]_{8}$, gave the highest surface areas but with crosslink densities ca $45 \%$ of theory. Furthermore, the pore size distributions were very broad. In contrast, the longest tethers, obtained from reactions of $\left[\mathrm{HMe}_{2} \mathrm{SiOSiO}_{1.5}\right]_{8}$ with $\left[\mathrm{CH}_{2}=\mathrm{CHMe}_{2} \mathrm{SiOSiO}_{1.5}\right]_{8}$, gave the lowest surface areas but with crosslink densities $80 \%$ of theory and with a narrow pore size distribution of $0.1-0.4 \mathrm{~nm}$. This pore size distribution could be accounted for if each cube was covalently bonded to six neighboring cubes ( $80 \%$ crosslink density) creating intercube pores of $0.1-0.2 \mathrm{~nm}$ in diameter and if some cubes were occasionally missing from the periodic structure (defects), accounting for the $0.3-0.4 \mathrm{~nm}$ pores. Furthermore, X-ray powder patterns of these materials indicated periodic assemblies as also suggested by the pore size distribution and crosslink densities.

Although the original materials offered potential as thermally stable (to $400^{\circ} \mathrm{C}$ ) low- $k$ dielectrics and also as porous media for chromatographic applications, for example, they could only be prepared by solution processing that required a catalyst and solvent removal. Consequently, we sought other systems that might be melt processable and thermally crosslinkable but with many of the same advantages. To this end, we explored the use of 4-vinyl-1-cyclohexene as a tether. The vinyl group permits hydrosilylative attachment to the cube, while the cyclohexenyl unit is much less susceptible to hydrosilylation under the same conditions but will thermally hydrosilylate at higher temperatures, offering the potential for melt processing. The results of these efforts are presented below.

\section{EXPERIMENTAL \\ Analytical methods}

\section{Solution NMR}

NMR analyses were run in $\mathrm{CDCl}_{3}$ with ${ }^{1} \mathrm{H}$ and ${ }^{13} \mathrm{C}$ data recorded using a Varian INOVA $400 \mathrm{MHz}$ spectrometer. ${ }^{1} \mathrm{H}$ NMR spectra obtained at $400 \mathrm{MHz}$ were collected using a $6000 \mathrm{~Hz}$ spectral width, a relaxation delay of $3.5 \mathrm{~s}$, a pulse width of $38^{\circ}$ and 30000 data points. ${ }^{13} \mathrm{C}\left\{{ }^{1} \mathrm{H}\right\}$ NMR spectra were obtained at $100.6 \mathrm{MHz}$ using a $25000 \mathrm{~Hz}$ spectral width, a relaxation delay of $1.5 \mathrm{~s}$, a pulse width of $40^{\circ}$ and 75000 data points. $\mathrm{CDCl}_{3}$ was used as internal reference for ${ }^{1} \mathrm{H}$ NMR (7.259 ppm) and ${ }^{13} \mathrm{C}$ NMR (77.23 ppm). ${ }^{29} \mathrm{Si}$ NMR spectra were recorded using a Bruker AM $360 \mathrm{MHz}$ spectrometer operating at $71.5 \mathrm{MHz}$ using $32000 \mathrm{~Hz}$ spectral width, a pulse width of $90^{\circ}$, a relaxation delay of $10.0 \mathrm{~s}, 32000$ data points and tetramethylsilane as external reference.

\section{Thermal analysis}

Dynamic thermal analysis - thermogravimetric analysis (DTA-TGA) of samples was performed using a SDT 2960 simultaneous DTA-TGA instrument (TA Instruments Inc., New Castle, DE). The instrument was calibrated with gold. Measurements were performed using $7-10 \mathrm{mg}$ samples placed in alumina crucibles and heated under a continuous flow of nitrogen or synthetic air $\left(110 \mathrm{~mL} \mathrm{~min}^{-1}\right)$, at $10^{\circ} \mathrm{C}$ $\min ^{-1}$ to $1000^{\circ} \mathrm{C}$. Calcined $\mathrm{Al}_{2} \mathrm{O}_{3}$ (Aluminum Co. of America, Pittsburgh, PA) was used as a reference analyte.

DSC traces were recorded using a 2910 differential scanning calorimeter (TA Instruments Inc., New Castle, DE) under nitrogen $\left(200 \mathrm{~mL} \min ^{-1}\right)$. The calorimeter was calibrated using indium as a reference. Samples $(20-30 \mathrm{mg})$ were typically heated to $200^{\circ} \mathrm{C}$ at $5^{\circ} \mathrm{C} \min ^{-1}$ and then allowed to cool naturally at $1^{\circ} \mathrm{C} \min ^{-1}$.

\section{Fourier transform infrared (FTIR) analysis}

Spectra were recorded on a Galaxy series FTIR 3000 spectrometer (Mattson Instruments, Madison, WI). Random cuttings of crystalline, optical-grade $\mathrm{KBr}$ from International Crystal Laboratories were used to prepare the sample. About $450 \mathrm{mg}$ of $\mathrm{KBr}$ were ground in a mortar with a pestle with $10 \mathrm{mg}$ sample 
added to make a $2 \mathrm{wt} \%$ mixture. The sample chamber was purged with nitrogen for a minimum of $5 \mathrm{~min}$ before data collection. A minimum of 128 scans was collected for each sample at a resolution of $4 \mathrm{~cm}^{-1}$. Peaks were identified manually by selecting the desired region with the cursor.

\section{Mechanical properties studies \\ Sample preparation}

An aluminium mold $(50 \times 15 \times 5 \mathrm{~mm})$ was made from aluminium foil. Finely ground [cyclohexenylethylMe $\mathrm{Me}_{2}$ $\left.\mathrm{SiOSiO}_{1.5}\right]_{4}-\left[\mathrm{HMe}_{2} \mathrm{SiOSiO}_{1.5}\right]_{4}$ (TCHS) (ca $3 \mathrm{~g}$ ) was then melted in the mold at $85^{\circ} \mathrm{C}$ in a vacuum oven (Lindberg Ltd, Blue M, Asheville, NC). The oven was then purged a minimum of three times with nitrogen and the sample was then heated gradually $\left(10^{\circ} \mathrm{C} \mathrm{h}^{-1}\right)$ to $150^{\circ} \mathrm{C}$ for 3 days under static vacuum $(150 \mathrm{mmHg})$. The resulting specimen $(30 \times 10 \times 2 \mathrm{~mm})$ was polished with an Econet III polisher/grinder (Buehler Ltd, Lake Bluff, IL) for DMA measurements.

\section{Dynamic mechanical analysis (DMA)}

DMA was conducted using a 2980 dynamic mechanical analyzer (TA Instrument, New Castle, DE). The sample was mounted on a single cantilever clamp. Mechanical properties were measured under nitrogen in step mode every $10^{\circ} \mathrm{C}$ from room temperature to $300^{\circ} \mathrm{C}$. Prior to each measurement, the furnace was kept at the set temperature for $10 \mathrm{~min}$ to ensure thermal equilibration.

Thermal mechanical analysis (TMA)

TMA samples were cut from the DMA test samples and polished to give $7 \times 5 \times 2 \mathrm{~mm}$ specimens. TMAs were run on using Perkin-Elmer TMA 7 (Wellesley, MA). The sample was placed under a quartz probe and heated in flowing helium from -50 to $230^{\circ} \mathrm{C}$ at $20^{\circ} \mathrm{C} \min ^{-1}$.

\section{X-ray powder diffraction (XRD) studies}

$\mathrm{XRD}$ patterns were obtained from $2 \theta=2^{\circ}$ to $30^{\circ}$ using a Rigaku X-ray diffractometer with $\mathrm{Cu} \mathrm{K} \alpha$ radiation $(1.542 \AA)$ operating at $40 \mathrm{kV}$ and $100 \mathrm{~mA}$, at a scanning speed of $2^{\circ} \mathrm{min}^{-1}$. The powder samples were prepared by milling DMA specimens. The samples were press-packed on a glass specimen holder.

\section{Dielectric constant measurements}

Dielectric constant measurements were obtained using a Hewlett Packard 419A instrument with sweep mode from $100 \mathrm{~Hz}$ to $40 \mathrm{MHz}$. A specimen was polished to $1.5 \mathrm{~mm}$ diameter and with a flat surface. The height of the specimen was measured directly with a caliper. The specimen was set between two copper electrodes to measure the dielectric constant at selected frequencies.

\section{Synthetic methods}

Solvents and reagents

4-Vinyl-1-cyclohexene, tetramethylammonium

dimethylchlorosilane and hydroxide $(25 \mathrm{wt} \%$ in methanol) were purchased from Sigma-Aldrich Co. Hexane, methanol and sodium sulfate were purchased from Fisher-Scientific. Tetraethoxysilane was purchased from Lancaster. Tetramethyldisiloxane (TMDS) was purchased from Gelest and polydimethylsiloxane (PDMS) was purchased from Petrarch Systems. All of the above reagents and solvents were used as received. Toluene (FisherScientific) used for hydrosilylation reactions was distilled from sodium/benzophenone under nitrogen.

\section{Catalyst}

Platinum dicyclopentadiene $[\mathrm{Pt}(\mathrm{dcp})]$ was prepared from hydrogen hexachloroplatinate(IV) hydrate (Sigma-Aldrich) and dicyclopentadiene using published procedures. ${ }^{43}$ Sufficient sample $(8 \mathrm{mg})$ was dissolved in distilled toluene $(10 \mathrm{~mL})$ to yield a $2.0 \mathrm{mmol}$ $\mathrm{L}^{-1}$ solution, which was stored under nitrogen.

\section{Octaanion solution}

To a $2 \mathrm{~L}$ round-bottomed flask equipped with a magnetic stir bar, $500 \mathrm{~mL}(4.75 \mathrm{~mol})$ tetramethylammonium hydroxide (25 wt\% in methanol), $258 \mathrm{~mL}$ $(6.55 \mathrm{~mol})$ methanol and $182 \mathrm{~mL}(10.1 \mathrm{~mol})$ distilled water was added. The flask was cooled in an ice bath and the system was maintained under nitrogen. Then $253 \mathrm{~mL}(1.13 \mathrm{~mol})$ tetraethoxysilane were added via an addition funnel. The solution turned cloudy and was stirred at room temperature overnight to produce a clear solution of tetramethylammonium octaanion in quantitative yield. ${ }^{44,45}$

\section{Octakis (dimethylsiloxy) octasilsesquioxane $e^{1-6}$}

To a $5 \mathrm{~L}$ round-bottomed flask equipped with a mechanical stirrer were added $2600 \mathrm{~mL}$ hexane and $436 \mathrm{~mL}(4.0 \mathrm{~mol})$ dimethylchlorosilane under nitrogen. The flask was placed in an ice bath, and $1000 \mathrm{~mL}$ of octaanion solution ([Si] $=1 \mathrm{~mol} \mathrm{~L}^{-1}$ ) was then added via an addition funnel over $2 \mathrm{~h}$. The final mixture was stirred continuously for another $2 \mathrm{~h}$. The two layers were separated with a $2 \mathrm{~L}$ separating funnel. The hexane layer was dried with sodium sulfate, gravity filtered through coarse filter paper and the solvent was removed by rotary evaporation to yield a white powder. This powder was rinsed with methanol and collected by vacuum filtration. The product was dried in a vacuum oven at $80{ }^{\circ} \mathrm{C}$ for $4 \mathrm{~h}$ to yield $91.5 \mathrm{~g}$ ( $72 \%$ of theoretical) of octakis(dimethylsiloxy)octasilsesquioxane (OHS; octahydrido spacer cube). The product was further purified by subliming at $200^{\circ} \mathrm{C}$ under vacuum or recrystallization from ether at room temperature.

Selected characterization data are as follows. FTIR $\left(\mathrm{KBr}, \mathrm{cm}^{-1}\right): 2966$ (vC-H alkane), $2144(v \mathrm{Si}-\mathrm{H})$, 1420 ( $v \mathrm{C}-\mathrm{H}$ bend), $1258\left(v \mathrm{Si}-\mathrm{CH}_{3}\right), 1096$ ( $\left.v \mathrm{Si}-\mathrm{O}\right)$, $566(\delta \mathrm{O}-\mathrm{Si}-\mathrm{O}), 465(v \mathrm{Si}-\mathrm{O}), 399(\delta \mathrm{O}-\mathrm{Si}-\mathrm{O}) .{ }^{1} \mathrm{H}$ $\mathrm{NMR}$ (ppm, $\mathrm{CHCl}_{3}$ as reference): 4.727 (q, $8 \mathrm{H}$, $\left.\mathrm{CH}_{3}-\mathrm{Si}-\mathrm{H}\right), 0.256,0.247$ (d, $\left.48 \mathrm{H}, \mathrm{CH}_{3}-\mathrm{Si}-\mathrm{H}\right)$. ${ }^{13} \mathrm{C} \mathrm{NMR}$ (ppm, $\mathrm{CDCl}_{3}$ as reference): 0.059 $\left(\mathrm{H}-\mathrm{Si}-\mathrm{CH}_{3}\right) .{ }^{29} \mathrm{Si} \mathrm{NMR}$ (ppm, TMS as reference): 
$0.380,-2.897$ (d, H-Si- $\left.\mathrm{CH}_{3}\right),-108.697$ (s, Si-O). Mass spectrum $(\mathrm{m} / z$, fragmentation, $\%$ intensity): $1016\left(\mathrm{M}^{+}, 36.5\right), 1003\left(\mathrm{M}^{+}-\mathrm{CH}_{3}, 100\right), 957$ $\left(\mathrm{M}^{+}-\mathrm{Si}\left(\mathrm{CH}_{3}\right) \mathrm{H}\right), 941\left(\mathrm{M}^{+}-\mathrm{OSi}\left(\mathrm{CH}_{3}\right)_{2} \mathrm{H}\right)$. TGA (air): ceramic yield $=88.7 \%$ actual, $94.3 \%$ calculated. TGA (nitrogen): ceramic yield $=0 \%$ actual as sample sublimes.

Tetrakis $\left[2-\left(3^{\prime}-\right.\right.$ cyclohexenyl $)$ ethyldimethylsiloxy]octasilsesquioxane (TCHS)

To a $250 \mathrm{~mL}$ Schlenk flask equipped with a magnetic stir bar and a condenser was added $21.38 \mathrm{~g}$ $(0.021 \mathrm{~mol})$ OHS. The flask was dried gently with a heat gun under flowing nitrogen. Distilled toluene $(100 \mathrm{~mL})$ was added by syringe to dissolve the cube completely, followed by 4-vinyl-1-cyclohexene $(10.9 \mathrm{~mL}, 0.08 \mathrm{~mol})$. Then $0.1 \mathrm{~mL}$ of a $2 \mathrm{mmol} \mathrm{L}^{-1}$ solution of $\operatorname{Pt}(\mathrm{dcp})$ was added and the reaction was heated at $90^{\circ} \mathrm{C}$ for $5 \mathrm{~h}$. Triphenylphosphine $(5 \mathrm{mg})$ was added to deactivate the $\operatorname{Pt}(\mathrm{dcp})$ catalyst, and the toluene solvent was removed by rotary evaporation. The remaining solid was rinsed with methanol and collected by vacuum filtration to yield $28.6 \mathrm{~g}$ (94\% of theoretical) of a white powder. TGA (air): ceramic yield $=66.9 \%$ actual, $66.2 \%$ calculated. TGA (nitrogen): ceramic yield $=66.1 \%$ (Figs 4 and 5). $\operatorname{DSC}\left(T_{\mathrm{m}} \approx 76^{\circ} \mathrm{C}, T_{\mathrm{c}} \approx 57^{\circ} \mathrm{C}\right)$ (Fig. 2$)$. The ${ }^{1} \mathrm{H}$ NMR, ${ }^{13} \mathrm{C}$ NMR and ${ }^{29} \mathrm{Si}$ NMR data are listed in Table 1 and FTIR data in Table 2.

Octakis [2-(3'-cyclohexenyl)

ethyldimethylsiloxy]octasilsesquioxane (OCHS)

To a $250 \mathrm{~mL}$ Schlenk flask equipped with a magnetic stir bar and a condenser was added $21.38 \mathrm{~g}(0.021 \mathrm{~mol})$ OHS. The reaction vessel was dried with a heat gun under nitrogen. Then 4-vinyl-1-cyclohexene $(21.9 \mathrm{~mL}, 0.168 \mathrm{~mol})$ was added by syringe, followed by $0.1 \mathrm{~mL}$ of $2.0 \mathrm{mmol} \mathrm{L}^{-1}$ solution of $\mathrm{Pt}(\mathrm{dcp})$. The reaction was heated at $90^{\circ} \mathrm{C}$ for $4 \mathrm{~h}$, and then allowed to cool. Cooling produced a solid mass which was broken up with a spatula, ground with a mortar and pestle, washed with methanol and collected by vacuum filtration to give a quantitative yield of a white powder, $38.5 \mathrm{~g}$ (97\% of theoretical). TGA (air): ceramic yield $=46.8 \%$ actual, $51.0 \%$ calculated. TGA (nitrogen): ceramic yield $=36.4 \% \quad$ (Figs 6 and 7 ). DSC (m.p. $74.1{ }^{\circ} \mathrm{C}$ ). The ${ }^{1} \mathrm{H}$ NMR, ${ }^{13} \mathrm{C}$ NMR and ${ }^{29} \mathrm{Si}$ NMR data are presented in Table 1 and the FTIR data in Table 2.

\section{Curing studies}

Thermal curing

Typical curing studies were done in circular aluminium pans $(44 \times 12.5 \mathrm{~mm})$ containing $c a 2.0 \mathrm{~g}$ of sample. Samples were heated in a vacuum oven (model V0914SA, Lindberg/Blue M, Asheville, NC) at $100^{\circ} \mathrm{C}$ under dynamic vacuum to melt the sample and volatilize residual solvent. The vacuum oven was then purged a minimum of three times with nitrogen, heated to $230^{\circ} \mathrm{C}$ over $c a 1 \mathrm{~h}$ and samples were cured at temperature for a minimum of $5 \mathrm{~h}$ under a static vacuum to produce clear solids.

\section{Radical curing}

In a mortar and pestle, $1 \mathrm{~g}$ of TCHS was mixed with $5 \mathrm{~mol} \%$ 2, 2'-azobisisobutyronitrile (AIBN; 0.006 g) and then heated at $100{ }^{\circ} \mathrm{C}$ in an aluminium pan under dynamic vacuum to remove any excess solvent. The reaction was then heated at $200^{\circ} \mathrm{C}$ for $6 \mathrm{~h}$ under nitrogen and static vacuum to produce a transparent,

Table 2. FTIR data for OHS, TCHS and OCHS

\begin{tabular}{lll}
\hline OHS $\left(\mathrm{cm}^{-1}\right)$ & \multicolumn{1}{c}{ TCHS $\left(\mathrm{cm}^{-1}\right)$} & \multicolumn{1}{c}{ OCHS $\left(\mathrm{cm}^{-1}\right)$} \\
\hline $2910(v \mathrm{C}-\mathrm{H}$ alkane $)$ & $3022(v \mathrm{C}-\mathrm{H}$ alkene $)$ & $3023(v \mathrm{C}-\mathrm{H}$ alkene $)$ \\
$2140(v \mathrm{Si}-\mathrm{H})$ & $2910(v \mathrm{C}-\mathrm{H}$ alkane $)$ & $2910(v \mathrm{C}-\mathrm{H}$ alkane $)$ \\
$1433(\mathrm{C}-\mathrm{H}$ bend $)$ & $2137(v \mathrm{Si}-\mathrm{H})$ & $1652(v \mathrm{C}=\mathrm{C})$ \\
$1260\left(v \mathrm{Si}-\mathrm{CH}_{3}\right)$ & $1652(v \mathrm{C}=\mathrm{C})$ & $1455(\mathrm{C}-\mathrm{H}$ bend $)$ \\
$1096(v \mathrm{Si}-\mathrm{O})$ & $1433(\mathrm{C}-\mathrm{H}$ bend $)$ & $1257\left(\nu \mathrm{Si}-\mathrm{CH}_{3}\right)$ \\
& $1258\left(v \mathrm{Si}-\mathrm{CH}_{3}\right)$ & $1096(\nu \mathrm{Si}-\mathrm{O})$ \\
& $1096(v \mathrm{Si}-\mathrm{O})$ & \\
\hline
\end{tabular}

Table 1. NMR data for vinylcyclohexene, OHS, TCHS, OCHS

\begin{tabular}{|c|c|c|c|}
\hline Compound & ${ }^{1} \mathrm{H} \mathrm{NMR}^{\mathrm{a}}$ (ppm) & ${ }^{13} \mathrm{C} \mathrm{NMR}^{\mathrm{b}}$ (ppm) & ${ }^{29}$ Si NMR ${ }^{c}$ (ppm) \\
\hline 4-Vinylcyclohexene & $\begin{array}{l}5.84 \text { (m, H-2); } 5.68 \text { (d, H-5, H-6); } \\
\quad 4.92-5.05 \text { (m, H-1); 2.26-1.39 } \\
\text { (m, H-3, H-4, H-7, H-8) }\end{array}$ & $\begin{array}{l}24.7 \text { (C-5); } 28.2 \text { (C-6); } 30.9 \text { (C-3); } 37.4 \\
\quad \text { (C-4); } 112.2 \text { (C-8); } 125.9 \text { (C-2); } \\
\quad 126.7 \text { (C-1); } 143.6 \text { (C-7) }\end{array}$ & \\
\hline TCHS & $\begin{array}{l}5.65(\mathrm{~s}, \mathrm{HC}=\mathrm{CH}) ; 4.73(\mathrm{~m}, \mathrm{Si}-\mathrm{H}) ; \\
\quad 2.04(\mathrm{ddd}, \mathrm{H}-4) ; 2.02(\mathrm{q}, \mathrm{H}-7) ; \\
\text { 1.63-1.55 (m, H-8); } 1.30(\mathrm{~m}, \\
\mathrm{H}-2) ; 1.18(\mathrm{~m}, \mathrm{H}-3) ; 0.61(\mathrm{t}, \mathrm{H}-1) ; \\
0.24\left(\mathrm{~d}, \mathrm{H}-\mathrm{Si}-\mathrm{CH}_{3}\right) ; 0.13(\mathrm{~s} \\
\left.\mathrm{CH}_{3}-\mathrm{Si}-\mathrm{C}\right)\end{array}$ & $\begin{array}{l}\text { 126.8, } 127.0(\mathrm{C}=\mathrm{C}) ; 36.4,31.6,29.6 \\
\text { 28.5, } 25.4\left(\mathrm{sp}^{3}-\mathrm{C} \text {, cyclohexene); }\right. \\
\text { 14.6 }\left(\mathrm{Si}-\mathrm{CH}_{2}\right) ; 0.08\left(\mathrm{CH}_{3}-\mathrm{Si}-\mathrm{H}\right) \\
\quad-0.46\left(\mathrm{CH}_{3}-\mathrm{Si}-\mathrm{CH}_{2}\right)\end{array}$ & $\begin{array}{l}13.78\left(\mathrm{CH}_{3}-\mathrm{Si}-\mathrm{CH}_{2}\right) ;-0.081 \\
-2.86\left(\mathrm{CH}_{3}-\mathrm{Si}-\mathrm{H}\right) ;-108.6 \\
(\mathrm{H}-\mathrm{Si}-\mathrm{O}-\mathrm{Si}-) ;-108.94 \\
\left(-\mathrm{CH}_{2}-\mathrm{Si}-\mathrm{O}-\mathrm{Si}-\right)\end{array}$ \\
\hline $\mathrm{OCHS}$ & $\begin{array}{l}5.64,5.65(\mathrm{~d}, \mathrm{HC}=\mathrm{CH}) ; 2.08(\mathrm{ddd}, \\
\mathrm{H}-4) ; 2.03(\mathrm{q}, \mathrm{H}-7) ; 1.66,1.56(\mathrm{~m}, \\
\mathrm{H}-8) ; 1.25-1.29(\mathrm{~m}, \mathrm{H}-2) ; 1.18 \\
(\mathrm{M}, \mathrm{H}-3)\end{array}$ & $\begin{array}{l}\text { 127.2, } 126.9(\mathrm{C}=\mathrm{C}) ; 36.4,31.9,29.9 \\
\text { 28.7, } 25.6\left(\mathrm{sp}^{3}-\mathrm{C}, \text { cyclohexene); }\right. \\
\text { 14.86 }\left(\mathrm{Si}-\mathrm{CH}_{2}\right) ;-0.173 \\
\left(\mathrm{CH}_{3}-\mathrm{Si}-\mathrm{CH}_{2}\right)\end{array}$ & $\begin{array}{l}13.49\left(\mathrm{CH}_{3}-\mathrm{Si}-\mathrm{CH}_{2}-\right) ; \\
\quad-108.86\left(-\mathrm{CH}_{2}-\mathrm{Si}-\mathrm{O}-\mathrm{Si}-\right)\end{array}$ \\
\hline
\end{tabular}

\footnotetext{
${ }^{\text {a }} \mathrm{CHCl}_{3}$ as reference.

${ }^{b} \mathrm{CDCl}_{3}$ as reference.

c TMS as reference.
} 
Table 3. FTIR data for cured resins

\begin{tabular}{|c|c|c|c|}
\hline TCHS self-cure $\left(\mathrm{cm}^{-1}\right)$ & $\mathrm{OCHS}$ w/OHS $\left(\mathrm{cm}^{-1}\right)$ & $\mathrm{OCHS}$ w/PDMS $\left(\mathrm{cm}^{-1}\right)$ & $\mathrm{OCHS}$ w/TMDS $\left(\mathrm{cm}^{-1}\right)$ \\
\hline & 3023 ( $v \mathrm{C}-\mathrm{H}$ alkene) & 3023 ( $v \mathrm{C}-\mathrm{H}$ alkene) & 3023 (vC-H alkene) \\
\hline 2916 (vC-H alkane) & 2924 (vC-H alkane) & 2917 (vC-H alkane) & 2917 (vC-H alkane) \\
\hline $2151(\nu \mathrm{Si}-\mathrm{H})$ & $2144(v \mathrm{Si}-\mathrm{H})$ & & \\
\hline $1653(\nu \mathrm{C}=\mathrm{C})$ & $1655(v \mathrm{C}=\mathrm{C})$ & $1652(v \mathrm{C}=\mathrm{C})$ & $1652(v \mathrm{C}=\mathrm{C})$ \\
\hline 1451 ( $(\mathrm{C}-\mathrm{H}$ bend) & $1448(v \mathrm{C}-\mathrm{H}$ bend $)$ & $1455(v \mathrm{C}-\mathrm{H}$ bend $)$ & $1448(\nu \mathrm{C}-\mathrm{H}$ bend $)$ \\
\hline $1259\left(v \mathrm{Si}-\mathrm{CH}_{3}\right)$ & $1258\left(v \mathrm{Si}-\mathrm{CH}_{3}\right)$ & $1258\left(v \mathrm{Si}-\mathrm{CH}_{3}\right)$ & $1258\left(v \mathrm{Si}-\mathrm{CH}_{3}\right)$ \\
\hline $1095(v \mathrm{Si}-\mathrm{O})$ & $1096(v \mathrm{Si}-0)$ & $1096(v \mathrm{Si}-\mathrm{O})$ & $1096(v \mathrm{Si}-\mathrm{O})$ \\
\hline
\end{tabular}

flexible disk. TGA (air): ceramic yield $=65.5 \%$. TGA (nitrogen): ceramic yield $=61.2 \%$ (Figs 10 and 11 ). FTIR data are given in Table 3.

\section{Reaction of OCHS with OHS}

Thermally promoted curing

Finely ground (mortar and pestle) mixtures of $0.73 \mathrm{~g}$ (0.0004 mol) OCHS and $0.37 \mathrm{~g}(0.0004 \mathrm{~mol})$ OHS, both with and without $0.1 \mathrm{~mL} \mathrm{Pt}(\mathrm{dcp})$ catalyst, were placed in aluminium pans in a vacuum oven and heated to $100^{\circ} \mathrm{C}$ under dynamic vacuum to remove any residual solvent. The vacuum oven was purged at least three times with nitrogen, and then ramped at $c a$ $8^{\circ} \mathrm{C} \min ^{-1}$ to $230^{\circ} \mathrm{C}$, and kept there for a minimum of $5 \mathrm{~h}$ under static vacuum $(150 \mathrm{mmHg})$. The mixture never became molten. After $5 \mathrm{~h}$, a brown, brittle solid was produced for both the catalyzed and uncatalyzed experiments. Improved curing was obtained if the triphenylphosphine from the synthesis was carefully removed by column chromatography.

\section{AIBN-promoted curing}

OCHS (0.73 g, $0.0004 \mathrm{~mol})$ and $0.37 \mathrm{~g}(0.0004 \mathrm{~mol})$ OHS were mixed with $5 \mathrm{~mol} \%$ AIBN (0.0015g) and ground with a mortar and pestle. The mixture was heated to $110^{\circ} \mathrm{C}$ under dynamic vacuum in an aluminium pan to remove any residual solvent. It was then ramped in nitrogen-purged vacuum oven at a rate of $c a 8^{\circ} \mathrm{C} \mathrm{min}^{-1}$ to $200^{\circ} \mathrm{C}$ for $6 \mathrm{~h}$ under static vacuum. The resulting product was an opaque, somewhat flexible solid. TGA (air): ceramic yield $=61.3 \%$ actual, $66.2 \%$ theoretical. TGA (nitrogen): ceramic yield $=59.9 \%$. FTIR data are listed in Table 3. (See Appendix A for details.)

\section{Reaction of OCHS with PDMS (see Appendix A for details)}

In an aluminium pan, $1 \mathrm{~g}(0.0005 \mathrm{~mol})$ of OCHS was heated at $120^{\circ} \mathrm{C}$ under dynamic vacuum to melt and remove residual solvent. Then $0.26 \mathrm{~mL}(0.00125 \mathrm{~mol})$ of hydrido-capped PDMS (molecular weight ca $400 \mathrm{~g}$ $\mathrm{mol}^{-1}$ ) was added along with $0.1 \mathrm{~mL}$ of $\mathrm{Pt}(\mathrm{dcp})$ and heated in a nitrogen-purged oven under static vacuum at $200^{\circ} \mathrm{C}$ for $5 \mathrm{~h}$. A clear, flexible disk was obtained which was $44 \mathrm{~mm}$ in diameter and ca $2-3 \mathrm{~mm}$ thick, depending on the amount of starting materials used.

The same reaction was performed by adding $5 \mathrm{~mol} \%$ of AIBN (0.0044 g), which was ground together with OCHS with a mortar and pestle. This mixture was heated under nitrogen and static vacuum at $200{ }^{\circ} \mathrm{C}$ for $6 \mathrm{~h}$. It produced an opaque, brittle solid. TGA (air): ceramic yield $=52.3 \%$ actual, $59.2 \%$ theoretical. TGA (nitrogen): ceramic yield $=49.7 \%$. FTIR data are listed in Table 3.

\section{Reaction of OCHS with TMDS (see Appendix A for details)}

In an aluminium pan, $1 \mathrm{~g}(0.50 \mathrm{mmol})$ of OCHS was heated at $120^{\circ} \mathrm{C}$ under dynamic vacuum to remove excess solvent, and melt the sample. Then, $0.26 \mathrm{~mL}(0.002 \mathrm{~mol})$ of TMDS and $0.1 \mathrm{~mL}$ of $\mathrm{Pt}(\mathrm{dcp})$ (2.0 mmol L $\mathrm{m}^{-1}$ solution in toluene) was added and ramped in a nitrogen-purged oven under static vacuum at $c a 8^{\circ} \mathrm{C} \min ^{-1}$ to $200^{\circ} \mathrm{C}$ for $5 \mathrm{~h}$. An opaque, brittle solid was obtained.

The same reaction was performed by adding $5 \mathrm{~mol} \%$ AIBN (0.004 g), which was ground together with OCHS with a mortar and pestle. This mixture was heated under nitrogen and static vacuum at $200^{\circ} \mathrm{C}$ for $6 \mathrm{~h}$. It produced an opaque and insoluble, brittle solid. TGA (air): ceramic yield $=41.4 \%$ actual, $45.4 \%$ theoretical. TGA (nitrogen): ceramic yield $=30.0 \%$. FTIR data are listed in Table 3. (See Appendix A for details.)

\section{RESULTS AND DISCUSSION}

In the following sections, we first describe the synthesis and characterization of ethylcyclohexenyl-substituted cubic silsesquioxanes. We then discuss their curing behavior under a variety of conditions followed by an evaluation of their thermomechanical and dielectric properties. These studies lead to some conclusions about their nanocomposite structures and properties.

\section{TCHS/OCHS}

TCHS is easily synthesized in $>90 \%$ yield via platinum-catalyzed hydrosilylation, as per reaction (1). 


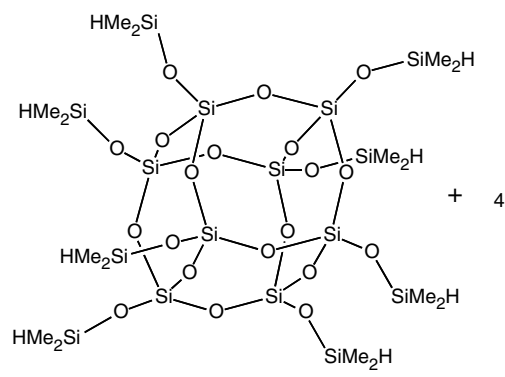<smiles>C=CC1CC=CCC1</smiles>

The resulting solid (actually an average of multiple substitution products and their isomers) is a lowmelting $\left(76^{\circ} \mathrm{C}\right)$, white crystalline powder that was characterized using ${ }^{1} \mathrm{H} \mathrm{NMR},{ }^{13} \mathrm{C} \mathrm{NMR},{ }^{29} \mathrm{Si} \mathrm{NMR}$ (Table 1), FTIR (Table 2), DSC (Figs 1 and 2), XRD (Fig. 3) and DTA-TGA (Figs 4 and 5). Likewise, OCHS is easily synthesized using identical conditions but with excess vinylcyclohexene giving a low-melting $\left(120^{\circ} \mathrm{C}\right)$, white crystalline solid.

\section{NMR analysis}

The ${ }^{1} \mathrm{H}$ NMR spectrum of the starting cube, OHS, exhibits two peaks, a doublet at $0.252 \mathrm{ppm}$, corresponding to the methyl groups, and an $\mathrm{Si}-\mathrm{H}$ peak that appears as a quintet centered at $4.727 \mathrm{ppm} .{ }^{1} \mathrm{H}$ NMR integration of TCHS shows a 1.00:0.96 ratio for $\mathrm{CH}_{3}-\mathrm{Si}-\mathrm{H}$ (0.25 ppm): $\left(\mathrm{CH}_{3}\right)_{2} \mathrm{Si}-\mathrm{CH}_{2} \quad(0.13 \mathrm{ppm})$ providing an average substitution of 4.02. Earlier efforts to synthesize methacrylate derivatives via hydrosilylation when analyzed by mass spectroscopy showed mono-through octasubstitution with an average equivalent to the tetrasubstituted species. ${ }^{46} \mathrm{We}$ assume this pattern holds true here. OCHS was also characterized by ${ }^{1} \mathrm{H}$ NMR, ${ }^{13} \mathrm{C}$ NMR, ${ }^{29} \mathrm{Si}$ NMR (Table 1), FTIR (Table 2), TGA-DTA (Figs 6 and 7) and XRD (Fig. 3). Following hydrosilylation, only the internal double bond remains, as indicated by a peak at $5.65 \mathrm{ppm}$ (Table 1), implying that reaction occurs solely at the vinyl position.<smiles>C=CC1CC=CCC1</smiles>

These results are further supported by the ${ }^{13} \mathrm{C}$ NMR analysis where 10 different carbon environments are expected and seen (Table 1). The ${ }^{13} \mathrm{C}$ NMR spectrum of OHS shows only one peak at $0.059 \mathrm{ppm}$ for

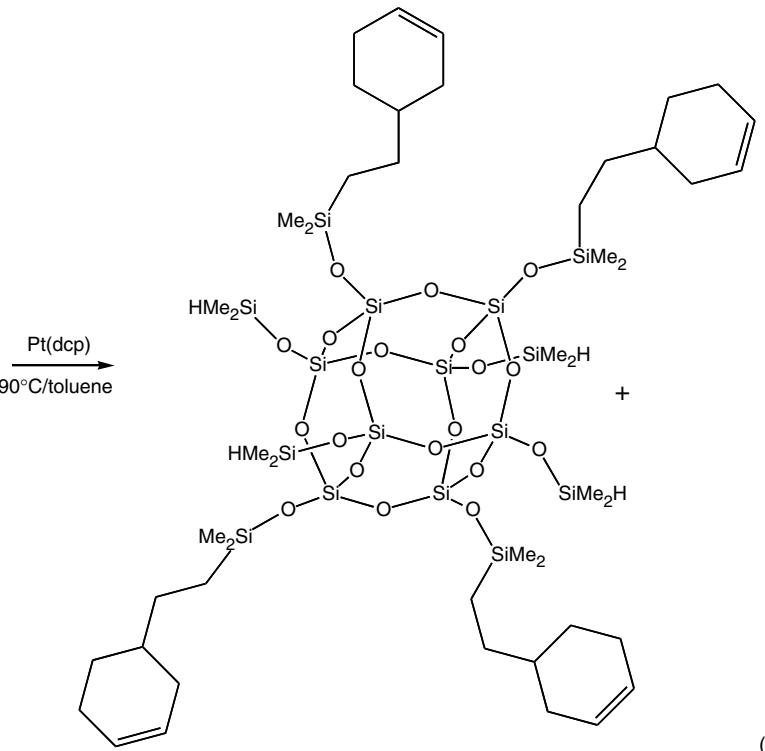

(1)

$\left(\mathrm{CH}_{3}\right)_{2} \mathrm{HSi}-\mathrm{O}$. Likewise, the ${ }^{29} \mathrm{Si} \mathrm{NMR}$ spectrum of OHS exhibits one peak at $-108.7 \mathrm{ppm}$, corresponding to $\left[\mathrm{HMe}_{2} \mathrm{SiOSiO}_{1.5}\right]_{8}$, and a doublet centered at $-1.26 \mathrm{ppm}$ for $\left[\mathrm{HMe}_{2} \mathrm{SiOSiO}_{1.5}\right]_{8}$. In contrast, the

${ }^{29} \mathrm{Si}$ NMR spectrum of TCHS shows four peaks (Table 1). The peak at $-108.9 \mathrm{ppm}$ is assigned to $\mathrm{O}-\mathrm{Si}-\mathrm{O}-\mathrm{Si}-\mathrm{CH}_{2}$ units, while the peak at $-108.7 \mathrm{ppm}$ represents unreacted $\mathrm{O}-\mathrm{Si}-\mathrm{O}-\mathrm{Si}-\mathrm{H}$ units. A doublet centered at $-1.39 \mathrm{ppm}$ reveals coupling of $(\mathrm{O}-\mathrm{Si}-\mathrm{O}-\mathrm{Si}-\mathrm{H})$ to the proton while the $\left(\mathrm{O}-\mathrm{Si}-\mathrm{O}-\mathrm{Si}-\mathrm{CH}_{2}\right)$ unit gives a singlet at $13.78 \mathrm{ppm}$.

For OCHS, neither ${ }^{1} \mathrm{H}$ NMR nor ${ }^{13} \mathrm{C}$ NMR spectrum shows any $\mathrm{Si}-\mathrm{H}$ or $\mathrm{CH}_{3}-\mathrm{Si}-\mathrm{H}$ peaks, indicating that the cube is fully substituted (Table 1). The ${ }^{13} \mathrm{C}$ NMR analysis shows only 9 carbon environments, as expected for the proposed structure. The ${ }^{1} \mathrm{H}$ NMR spectrum shows only a singlet at $0.12 \mathrm{ppm}$ for $\mathrm{CH}_{3}-\mathrm{Si}-\mathrm{CH}_{2}$, indicating the absence of $\mathrm{CH}_{3}-\mathrm{Si}-\mathrm{H}$ coupling. The ${ }^{29} \mathrm{Si}$ NMR spectrum exhibits two singlets at -108.9 and $13.4 \mathrm{ppm}$ (Table 1) again indicating complete substitution.

\section{FTIR analysis}

The FTIR spectrum of TCHS shows an expected $v \mathrm{C}-\mathrm{H}_{\text {alkene }}$ band at $3023 \mathrm{~cm}^{-1}$, a $v \mathrm{C}=\mathrm{C}$ band at $1652 \mathrm{~cm}^{-1}$ for the internal double bond and a $\nu \mathrm{Si}-\mathrm{H}$ peak $\left(2137 \mathrm{~cm}^{-1}\right)$ for unreacted $\mathrm{Si}-\mathrm{H}$ groups (Table 2).

The OCHS spectra are similar, lacking only a $\nu \mathrm{Si}-\mathrm{H}$ peak. Both systems exhibit $\nu \mathrm{Si}-\mathrm{O}$ bands at $1096 \mathrm{~cm}^{-1}$, characteristic of the cubic core structure, and useful as an internal standard. More detailed FTIR studies on cubic silsesquioxanes can be found in papers by Calzaferri and c-workers. ${ }^{47-49}$

\section{DSC analysis}

DSC cycling of TCHS to $300^{\circ} \mathrm{C}$ is shown in Fig. 1 . In the first heating cycle, an endotherm due to melting $\left(T_{\mathrm{m}}\right)$ is observed beginning near $70^{\circ} \mathrm{C}$. An exotherm is then observed with an onset close to $150^{\circ} \mathrm{C}$ and 
a maximum at $220^{\circ} \mathrm{C}$. In the second cycle, neither peak is observed suggesting that thermally promoted hydrosilylation occurs, forming ethylcyclohexyl links (tethers) between cube vertices.

Fig. 2 shows DSC traces of TCHS heated to $150^{\circ} \mathrm{C}$. The intent is to examine its behavior below the curing temperature. In the first cycle, an endotherm appears with a maximum at $76^{\circ} \mathrm{C}$ for $T_{\mathrm{m}}$ and on the cooling cycle a weak exotherm appears at $57^{\circ} \mathrm{C}$ that may correspond to $T_{\mathrm{c}}$. In the second cycle, the endotherm for melting broadens, the maximum shifts to $60^{\circ} \mathrm{C}$ and the exotherm disappears.

These results can be explained if we assume that on precipitation from solution we produce a partially crystalline material. On heating, the crystalline form melts but if the melt has a limited propensity to crystallize on cooling, expected for a material that consists of a mixture of substituents, then an amorphous phase forms on cooling that can be expected to have a lower melting temperature.

\section{XRD studies}

Fig. 3 shows powder patterns for OHS, TCHS, OCHS and thermally cured TCHS (resin). The XRD data are best described by using the OHS powder pattern as a reference point. Three primary peaks seen for OHS are at $8.3^{\circ}, 18.9^{\circ}$ and $24.4^{\circ}$ indicating a crystalline material. Indeed, the crystal structure is known. ${ }^{50}$ These peaks represent periodic distances of $1.1,0.5$ and $0.3 \mathrm{~nm}$ and are assigned to the (100) or (010), (120) and (112) planes, respectively. The $0.5 \mathrm{~nm}$

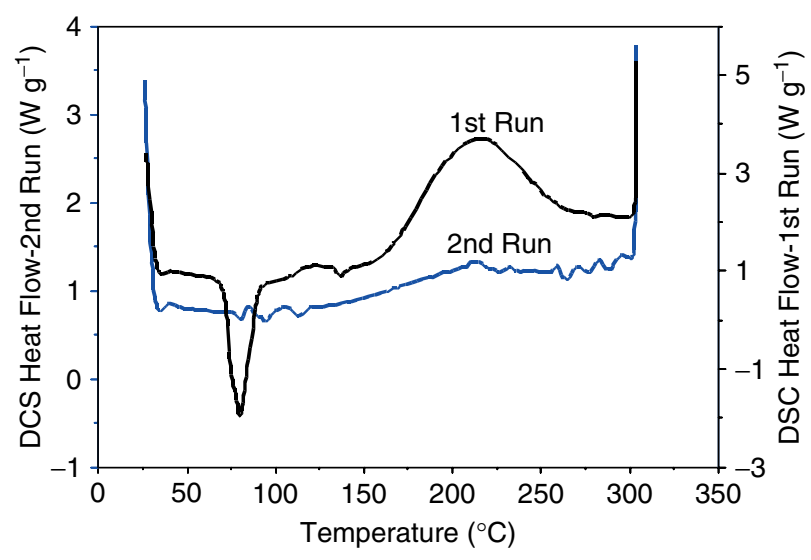

Figure 1. DSC traces of TCHS on heating through two cycles to $300^{\circ} \mathrm{C}$.

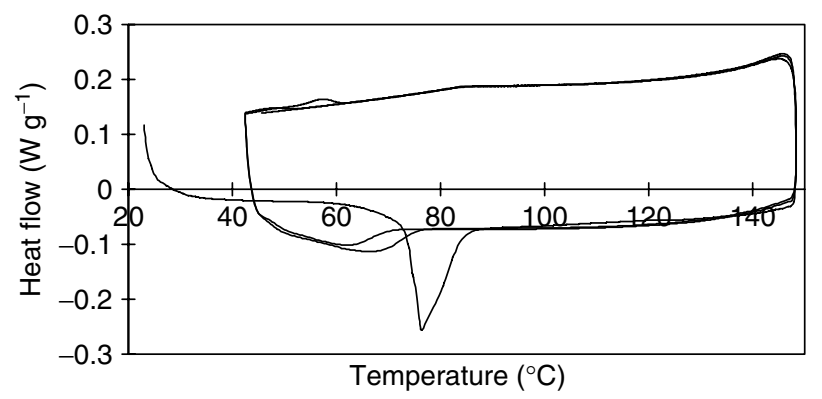

Figure 2. DSC traces of $\mathrm{TCHS}$ (up to $150^{\circ} \mathrm{C}$ ). distance likely corresponds to the cube (core) body diagonal. The $0.3 \mathrm{~nm}$ peak likely corresponds to the separation between the $4-4^{\prime}$ rings of the cubes - the distance between cube faces.

The TCHS material is only partially crystalline as suggested by the broad peak at $7.3^{\circ}$, indicative of a larger unit cell $(1.3-1.4 \mathrm{~nm})$, as might be expected for the irregularly substituted cube. The peak at $18.9^{\circ}$ shifts only slightly to $18.5^{\circ}$ and does not exhibit any broadening indicating a direct relationship to the core structure, as suggested above. Also, the peak at $24.4^{\circ}$ disappears. In the OCHS material, we see a similar pattern. The lowest peak shifts further to $6.5^{\circ}$ indicating a slight but further increase in unit cell size. A similar shift to slightly lower angles gives a peak at $18.1^{\circ}$. Finally, the crosslinked resin produced by thermal promotion of hydrosilylation also exhibits some ordering. This is discussed further below.

\section{Thermal properties}

For reference purposes, the TGAs of OHS in nitrogen and air were run (not shown). OHS sublimes completely in nitrogen beginning at about $230^{\circ} \mathrm{C}$ giving no ceramic yield. In air, it gives a ceramic yield of $85-90 \mathrm{wt} \%$ (94.3 wt\% theory) depending on the ramp rates as some of the material sublimes before it oxidizes. Note that if the ramp rates are too fast in air, OHS will oxidize explosively.

TGA traces of TCHS in nitrogen and air are shown in Figs 4 and 5, respectively. In both systems, an exotherm is seen at $c a 190^{\circ} \mathrm{C}$ that corresponds to thermally promoted hydrosilylative crosslinking. In nitrogen, the thermally crosslinked material is stable to $>400^{\circ} \mathrm{C}$ and then degrades slowly with a final char yield of $c a 70 \mathrm{wt} \%$. In air (Fig. 5) the $190^{\circ} \mathrm{C}$ exotherm is also accompanied by a slight mass gain as some $\mathrm{Si}-\mathrm{H}$ oxidation likely occurs concurrent with thermally promoted hydrosilylation. A second exotherm is seen beginning around $350^{\circ} \mathrm{C}$ associated with mass loss as the system oxidizes. The final ceramic yield is 66.1 wt $\%$ which is close to the calculated ceramic yield of $64 \mathrm{wt} \%$ for an average of four ethylcyclohexenyl substituents. These data are in good agreement with the ${ }^{1} \mathrm{H}$ NMR integration.

Related TGA studies of OCHS in nitrogen and air are presented in Figs 6 and 7. The TGA run in nitrogen (to $1000^{\circ} \mathrm{C}$ ) gives a ceramic yield of

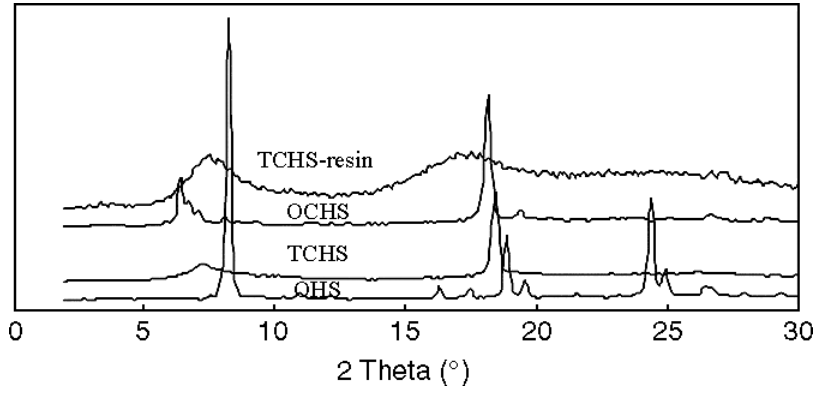

Figure 3. XRD data for $\mathrm{OHS}, \mathrm{TCHS}, \mathrm{OCHS}$ and thermally cured TCHS resin $(\times 5)$. 


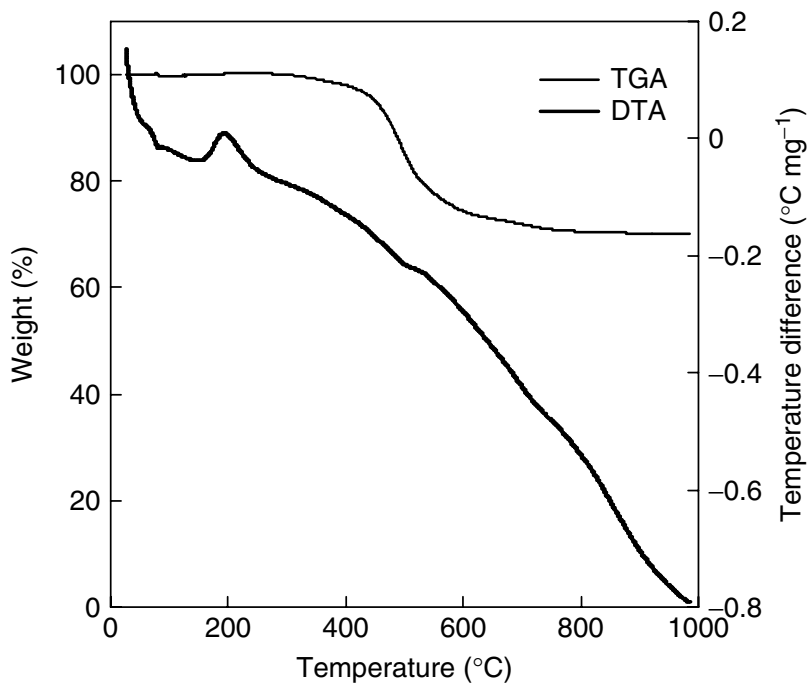

Figure 4. TGA/DTA of TCHS in nitrogen; ramp rate $=10^{\circ} \mathrm{C} \mathrm{min}^{-1}$.

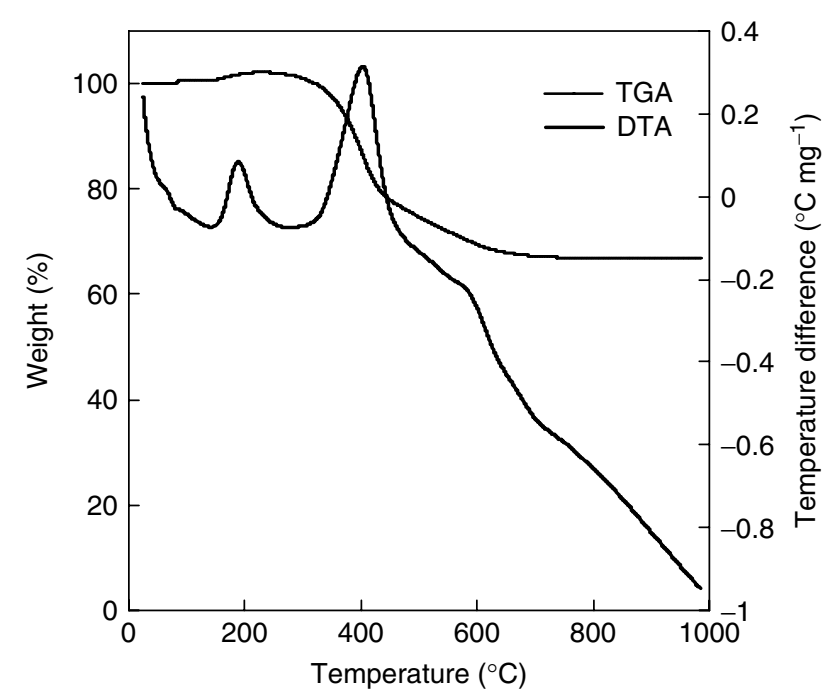

Figure 5. TGA/DTA of TCHS in air; ramp rate $=10^{\circ} \mathrm{C} \mathrm{min}^{-1}$.

$36.4 \mathrm{wt} \%$ (versus $49 \%$ theory), with most mass loss between 450 and $550^{\circ} \mathrm{C}$. A small exotherm, seen at $c a 200^{\circ} \mathrm{C}$, likely arises from thermally promoted hydrosilylation from residual $\mathrm{Si}-\mathrm{H}$ groups. A small endotherm is seen centered at about $500^{\circ} \mathrm{C}$. The low ceramic yield and endotherm in the DTA suggest that some OCHS sublimes under nitrogen; however, the material remains thermally stable to about $400^{\circ} \mathrm{C}$. This suggests that it remains a liquid until it sublimes or decomposes. Perhaps, it may be useful as lubricant, especially in a fully hydrogenated form.

In air, the DTA/TGA of OCHS (Fig. 7) shows an exotherm at $c a 190^{\circ} \mathrm{C}$ with a mass gain due to oxidation of residual $\mathrm{Si}-\mathrm{H}$ groups whose existence is suggested above. The ceramic yield in air is $46.8 \%$ (theory: $49.0 \%$ ). This ceramic yield is $2 \%$ lower than expected and may be due to some competitive sublimation. The DTA trace shows irregular exotherms and endotherms between 400 and $450^{\circ} \mathrm{C}$ that are likely a combination of the sublimation process and oxidative degradation processes.

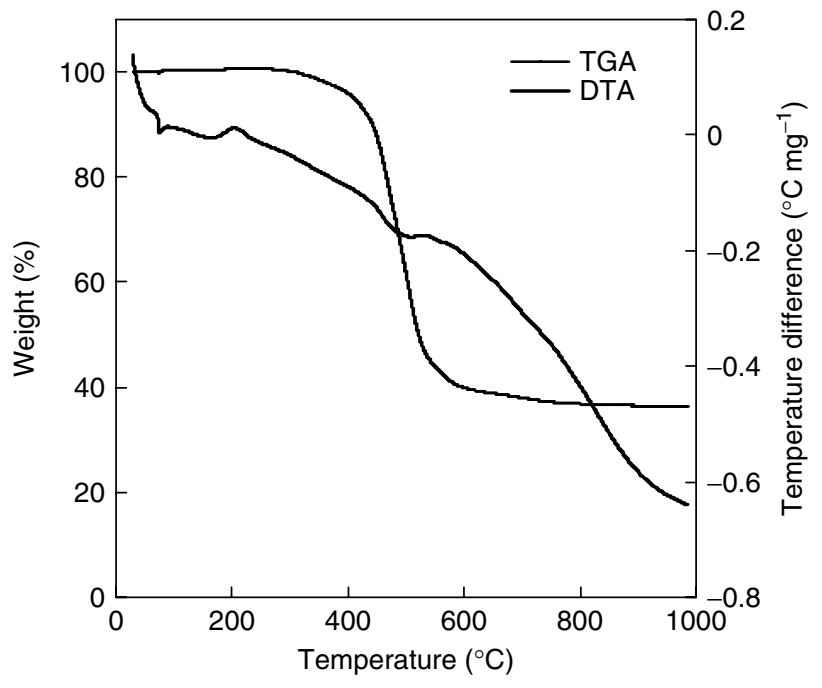

Figure 6. TGA/DTA of $\mathrm{OCHS}$ in nitrogen; ramp rate $=10^{\circ} \mathrm{C} \mathrm{min}^{-1}$.

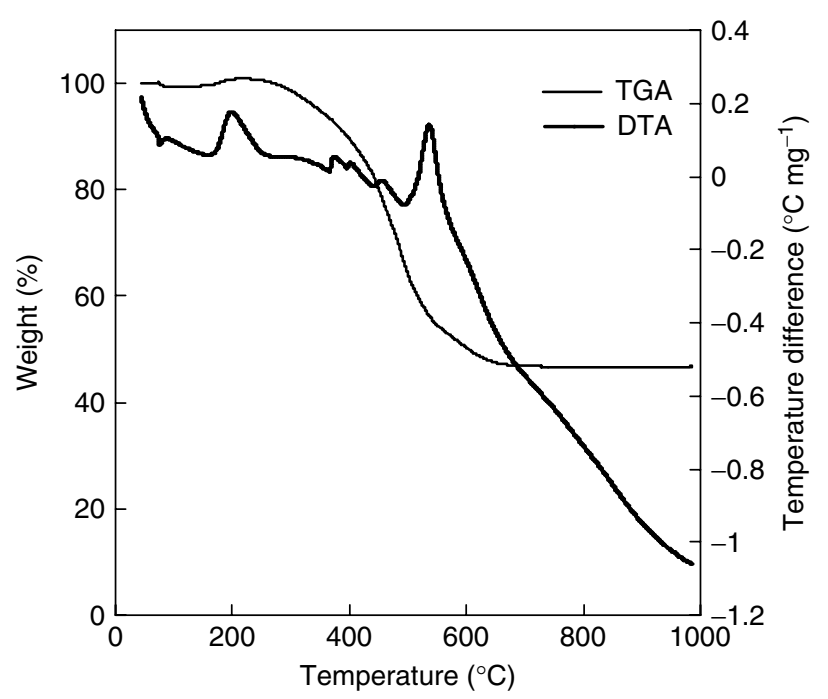

Figure 7. TGA/DTA of $\mathrm{OCHS}$ in air; ramp rate $=10^{\circ} \mathrm{C} \mathrm{min}^{-1}$.

The above DTA/TGA studies provide the basis for conducting bulk polymerization studies to produce larger scale samples for a variety of tests. The following section on curing discusses efforts to make fully crosslinked polymers from TCHS and OCHS.

\section{Curing studies}

The studies discussed in this section are divided into self-curing, radical-initiated curing and curing with chain extenders. We begin with the TCHS studies.

\section{TCHS self-curing}

Small samples ( $c a 2 \mathrm{~g}$ ) of finely ground TCHS powder were cured at $200^{\circ} \mathrm{C}$ for $6 \mathrm{~h}$ in aluminium pans $(44 \times 12.5 \mathrm{~mm})$ under nitrogen in a sealed vacuum oven. The cured product gave somewhat flexible, transparent disks with some cracks. Attempts to form tensile specimens produced hard, clear solids at the exposed portions of the mold, but left the interior tacky and incompletely cured. Increasing the cure temperature and time to $230^{\circ} \mathrm{C}$ for $8 \mathrm{~h}$ gave better 
results, but interior sections remained tacky. If the triphenylphosphine used to deactivate the platinum catalyst is not added, the specimen obtained was harder and more brittle.

Fig. 8 shows spectra of TCHS and a selfcured sample. On curing, the intensities of the $v \mathrm{C}-\mathrm{H}_{\text {alkene }}\left(>3000 \mathrm{~cm}^{-1}\right), v \mathrm{Si}-\mathrm{H}\left(2151 \mathrm{~cm}^{-1}\right)$ and $\nu \mathrm{C}=\mathrm{C}\left(1653 \mathrm{~cm}^{-1}\right)$ peaks decrease considerably relative to $v \mathrm{C}-\mathrm{H}_{\text {alkane, }}$, but do not completely disappear indicating that the cube is not $100 \%$ crosslinked following $8 \mathrm{~h}$ of curing. Thus, crosslinking appears to occur by thermally promoted hydrosilylation of the internal double bond. It is likely that $100 \%$ crosslinking is not possible due to steric and/or viscosity constraints. Also possible is that the distribution of the functional groups at the cube vertices is not completely regular as discussed below.

Figure 9 provides a schematic model of crosslinked TCHS. Based on this model and our previous studies ${ }^{27}$ one might anticipate nanoporosity in this system (see below).

The addition of $5 \mathrm{~mol} \%$ AIBN to TCHS produced a material similar to the uncatalyzed experiment, yet the polymer was more flexible without cracks. FTIR analysis of the AIBN-cured product revealed a spectrum essentially identical to that of the self-cured material. Detailed studies on AIBN-promoted curing are given in Appendix A.

The TMA curve for the TCHS resin (Fig. 10) suggests a possible $T_{\mathrm{g}}$ near $70^{\circ} \mathrm{C}$. Although we also looked for $T_{\mathrm{g}}$ in the DMA trace, the samples were too brittle for study. Consequently, it is not clear if the change in slope at $70^{\circ} \mathrm{C}$ in the TMA trace should be assigned to $T_{\mathrm{g}}$ or not. If it is a real $T_{\mathrm{g}}$ then it can

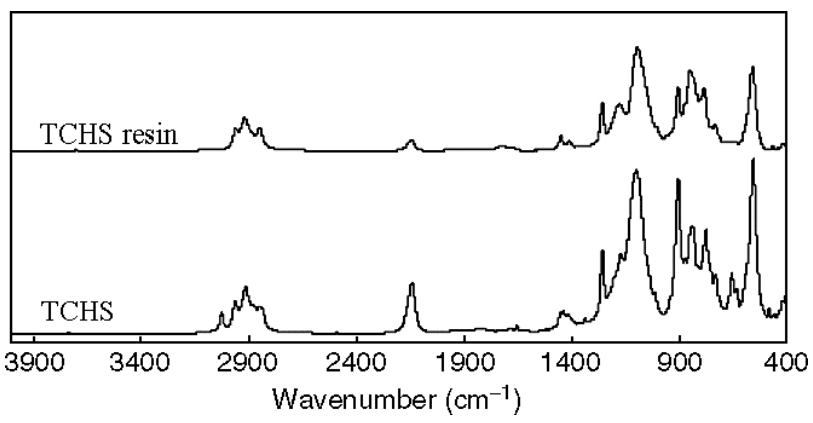

Figure 8. FTIR spectra of TCHS before and after thermal curing at $230^{\circ} \mathrm{C}$ for $8 \mathrm{~h}$ under nitrogen. only be assigned to movement of cyclohexyl rings, e.g. between chair and boat configurations, or to unreacted functional groups.

The coefficients of thermal expansion (CTEs) are 125 and $220 \mathrm{ppm}{ }^{\circ} \mathrm{C}^{-1}$ below and above $70^{\circ} \mathrm{C}$, respectively. As a reference, CTE values for typical silicone rubbers are $200-300 \mathrm{ppm}{ }^{\circ} \mathrm{C}^{-1}, 51$ also in accord with some of the epoxy resin systems we have studied recently. ${ }^{35}$

The XRD pattern of the TCHS resin magnified 5 times (Fig. 3) reveals broad weak peaks centered at $7.5^{\circ}$ and $17.5^{\circ}$ suggesting some periodicity within the resin structure. These peaks are relatively close to the peak positions in TCHS suggesting only modest changes in the cured structure. The fact that there is an XRD pattern at all may be attributed to the flexibility of the resulting ethylcyclohexyl tethers that may allow some ordering in the almost fully crosslinked system.

It is important to note that these systems should be true three-dimensional networks if the attachment of the ethylcyclohexenyl groups around the cage occurs in a random or statistical fashion. Indeed, random attachment seems necessary to obtain high crosslinked densities. The alternative perspective is that attachment is highly ordered, e.g. occurring only on one face of any cube. This would then lead to curing to form a ladder structure as suggested in Fig. 9. These are two extremes that for the moment we cannot differentiate between. But there is one mechanistic argument that can be made for attachment of all functional groups on one face.

The FTIR data in Fig. 8 suggest that only small amounts of $\mathrm{Si}-\mathrm{H}$ remain. This is also supported by the small $(1-2 \mathrm{wt} \%)$ mass gains in the TGA trace seen at near $200^{\circ} \mathrm{C}$ in Fig. 7 suggesting that very little

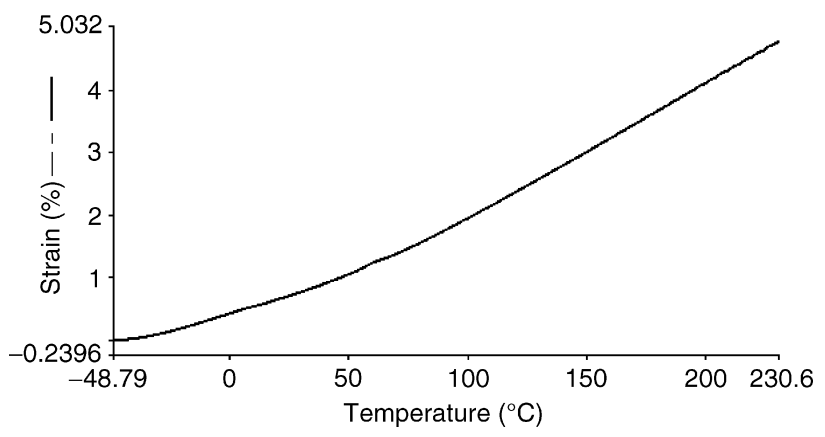

Figure 10. Thermomechanical analysis of cured TCHS resin.

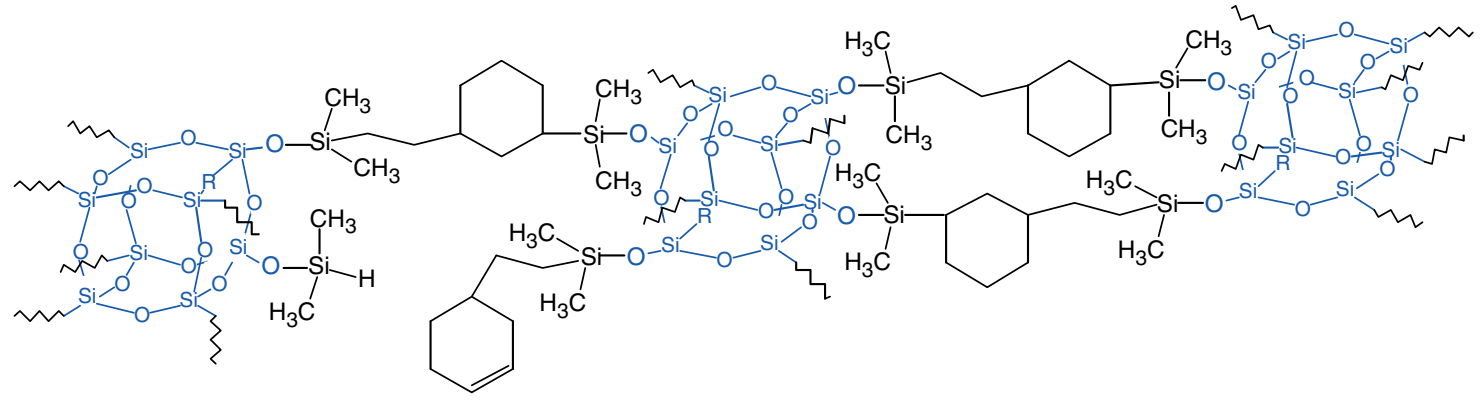

Figure 9. Structural model of crosslinked TCHS polymer. 
$\mathrm{Si}-\mathrm{H}$ is left to oxidize after curing. One interpretation may be that hydrosilylation is actually more selective than random. We have previously suggested that a platinum catalyst species may react selectively around one cube face simply on the basis of the higher statistical likelihood of reacting with another $\mathrm{Si}-\mathrm{H}$ unit on that face. ${ }^{42}$ This would lead on crosslinking to the ladder structure shown in Fig. 9 which might explain the high CTEs observed relative to highly crosslinked cage epoxy resins we have made with CTEs well below $100 \mathrm{ppm}^{\circ} \mathrm{C}^{-1}$. These issues remain unresolved at present.

Porosimetry studies were undertaken to determine if the resulting materials exhibited well-defined microporosity as in the case with the vinyl cube studies noted above. Surprisingly, after many repeated efforts by several individuals and the BET surface area measurements (Micromeretics ASAP 2000) manufacturer as well, it was determined that these materials were completely non-porous. At first this was quite surprising but these results are identical to those found by Loy and Shea, on studies of silsesquioxanes produced by hydrolysis of $(\mathrm{EtO})_{3} \mathrm{Si}\left(\mathrm{CH}_{2}\right)_{x} \mathrm{Si}(\mathrm{OEt})_{3}$ (and related compounds) in both acid and base, where $x=2-8$. Only the materials produced with $x=2$ were porous. ${ }^{4}$

\section{Dielectric constant measurements}

The model of Fig. 9 suggests the potential for welldefined porosity as found for materials with shorter tethers. Thus, before learning that these materials are not porous, we began measurements of their dielectric constants. Generally, the dielectric constants of silsesquioxane materials are known to be low. ${ }^{37}$ Hence one goal of the work reported here was to develop spin-on liquids that generate their own porosity on thermally curing and therefore generate inherently low dielectric constant coatings. The dielectric constant for a specimen prepared from TCHS was measured with sweep mode $(100 \mathrm{~Hz}-40 \mathrm{MHz})$ and found to range from $2.90(100 \mathrm{kHz})$ to $2.80(3 \mathrm{MHz})$. Although there is no apparent porosity, these values compare favorably with those currently in use for interlayer dielectrics but must fall to values of 1.8-2.0 for newer generations of interlayer dielectrics. ${ }^{52}$

For example, dielectric constants for films made of polymeric versions of $\mathrm{T}_{8}{ }^{\mathrm{H}}, \mathrm{T}_{8}{ }^{\mathrm{Me}}$ and $\mathrm{T}_{8}{ }^{\mathrm{Ph}}$ on silicon wafers have been measured (at room temperature) as 3.0, 2.9 and 2.8, respectively. ${ }^{52}$ These results can be interpreted to indicate that the dielectric constants of these materials derive primarily from the cube structure with limited influence by the tether length or structure.

\section{OCHS curing with OHS}

Attempts were made to react OCHS with equal molar amounts of OHS by dissolving it in molten OCHS with $c a 1 \mathrm{~g}$ quantities. Aluminium pans with finely ground (mortar and pestle) OCHS and OHS were heated to $230^{\circ} \mathrm{C}$ for $6 \mathrm{~h}$ under nitrogen in a sealed vacuum oven with or without $\operatorname{Pt}(\mathrm{dcp})$ catalyst. OCHS becomes molten, but OHS appears to be insoluble by visual inspection. Both experiments gave brown, brittle solids.

Samples of cured products, washed with hexane, were insoluble indicating that some crosslinking occurred since both OCHS and OHS are soluble in hexane. Crosslinking is not $100 \%$ complete because FTIR (Table 2) bands show $\nu \mathrm{C}-\mathrm{H}_{\text {alkane }} \quad\left(2924 \mathrm{~cm}^{-1}\right): \nu \mathrm{Si}-\mathrm{H} \quad\left(2144 \mathrm{~cm}^{-1}\right): \nu \mathrm{C}-$ $\mathrm{H}_{\text {alkene }}\left(3023 \mathrm{~cm}^{-1}\right): v \mathrm{C}=\mathrm{C}\left(1655 \mathrm{~cm}^{-1}\right)$ peaks in a 1:0.59:0.81:0.59 ratio, indicating that unreacted $\mathrm{Si}-\mathrm{H}$ and $\mathrm{C}=\mathrm{C}$ groups remain.

An improved material was made by mixing a $1: 1$ molar ratio of OCHS with OHS and $5 \mathrm{~mol} \%$ AIBN. After curing at $200^{\circ} \mathrm{C}$ for $6 \mathrm{~h}$ in nitrogen, a clear flexible disk was obtained. Some phase separation was seen in the form of opaque and transparent areas in the sample, most likely due to incomplete dissolution of OHS into the OCHS.

FTIR data (Table 3) reveal identical peaks for both the AIBN-initiated and uninitiated polymerizations. In comparison to $\nu \mathrm{C}-\mathrm{H}_{\text {alkane }}\left(2924 \mathrm{~cm}^{-1}\right)$, fairly weak $\nu \mathrm{Si}-\mathrm{H}\left(2144 \mathrm{~cm}^{-1}\right), \nu \mathrm{C}=\mathrm{C}\left(1652 \mathrm{~cm}^{-1}\right)$ and $\nu \mathrm{C}-\mathrm{H}_{\text {alkene }}$ peaks $\left(3023 \mathrm{~cm}^{-1}\right)$ are seen in these spectra in a 1:0.44:0.56:0.48 ratio.

This indicates that even with AIBN present, crosslinking was not $100 \%$ complete. However, in comparison to FTIR ratios for the uninitiated reaction discussed above, the decreases in $\mathrm{Si}-\mathrm{H}$ and $\mathrm{C}=\mathrm{C}$ indicate a greater degree of crosslinking between OCHS and OHS when AIBN is present.

DTA/TGA traces of this polymer in air show a slight mass gain (ca $1.5 \%)$ at $c a 210^{\circ} \mathrm{C}$ (Fig. 11), indicating oxidation of residual $\mathrm{Si}-\mathrm{H}$ groups. The TGA then shows a steep mass loss at $c a 300^{\circ} \mathrm{C}$.

The DTA shows exotherms centered at 280 and $320^{\circ} \mathrm{C}$, corresponding to mass gains first from oxidation of residual $\mathrm{Si}-\mathrm{H}$ and second from oxidative decomposition of the crosslinked material. The found ceramic yield of $61.3 \mathrm{wt} \%$ differs from theory $(66.2 \%)$

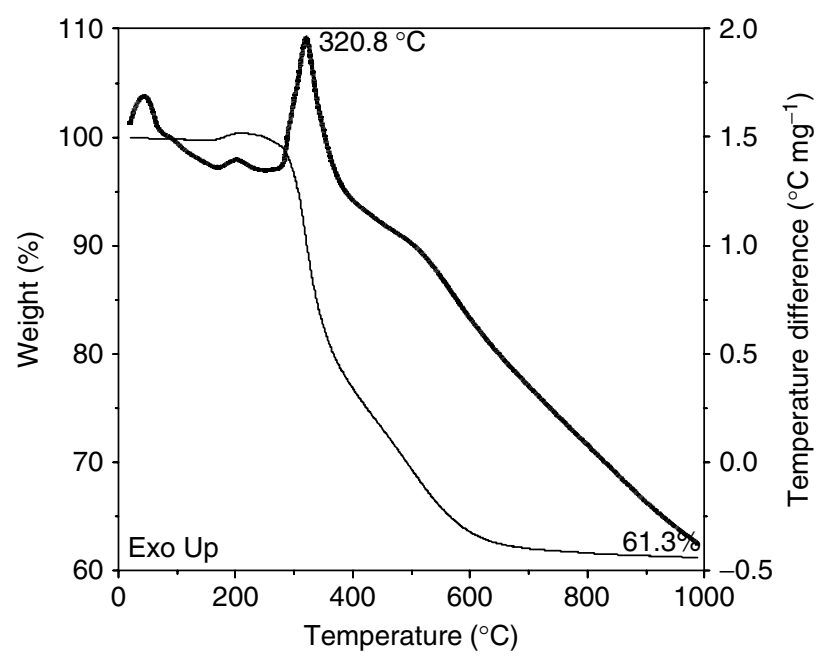

Figure 11. TGA/DTA in air of OCHS:OHS 1:1; ramp rate $=10^{\circ} \mathrm{C} \mathrm{min}^{-1}$. 


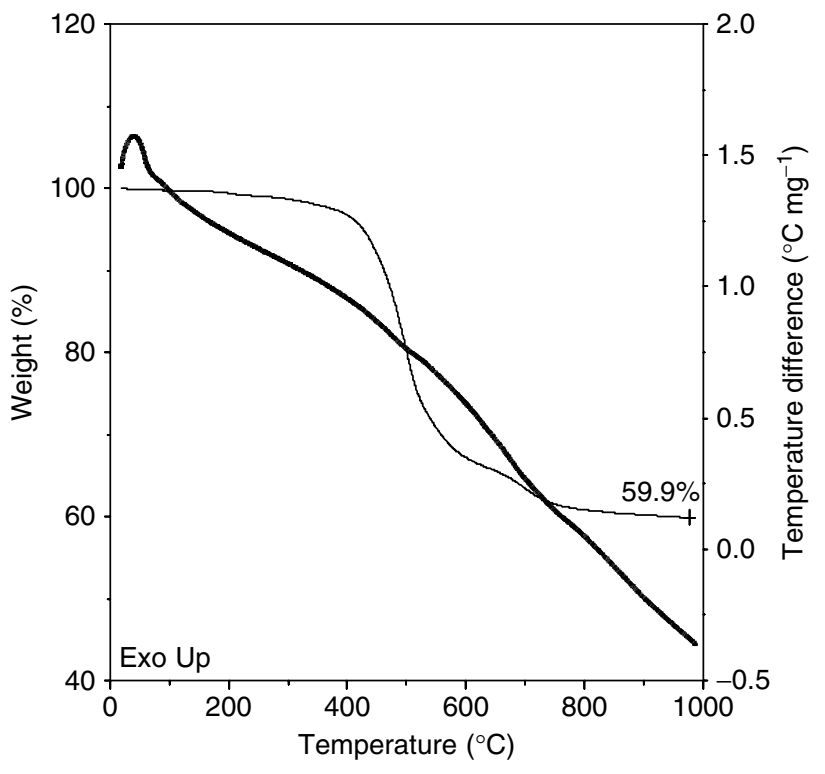

Figure 12. TGA/DTA in nitrogen of OCHS:OHS 1:1; ramp rate $=10^{\circ} \mathrm{C} \mathrm{min}^{-1}$.

likely because of residual unincorporated OHS, which sublimes at $\mathrm{ca} 230^{\circ} \mathrm{C}$ (see above). In nitrogen (Fig. 12), the polymer is stable to $c a 400^{\circ} \mathrm{C}$ with a ceramic yield of $59.9 \mathrm{wt} \%$. This latter result supports the likely partial sublimation of unreacted material. No exotherms are seen in nitrogen as no oxidative processes are possible. This also indicates that all crosslinking processes from thermally promoted hydrosilylation are complete in the original curing steps.

Similar OCHS coupling studies were run using a hydrido-endcapped PDMS and also TMDS. These studies gave materials of similar low quality and properties and are recorded in Appendix A.

\section{CONCLUSIONS}

The use of bifunctional hydrocarbon reactants wherein the reactivity of one functional group is greater than the second allows the development of self-curing silsesquioxanes. The reaction of vinylcylcohexene with OHS provides tetra- and octacyclohexenylethyloctasilsesquioxane. The tetra-bifunctional (average degree of functionalization) melts to give low-viscosity liquids that can be cast and subsequently cured to highly crosslinked, transparent flexible nanocomposites. These nanocomposites offer thermal stabilities of $\geq 400^{\circ} \mathrm{C}$ and good low- $k$ dielectric properties without being nanoporous. The absence of UV-absorbing groups suggests that they may also offer promise for deep-UV photoresist applications.

\section{ACKNOWLEDGEMENTS}

RML, LV and NT thank the FAA, NIDR and Matsushita Electric Works Ltd for generous support of this work. A significant portion of this work was completed by LV as part of her honors chemistry senior thesis.

\section{REFERENCES}

1 Voronkov MG and Lavrent'yev VI, Top Curr Chem 102:199 (1982).

2 Baney RH, Itoh M, Sakakibara A and Suzuki T, Chem Rev 95:1409 (1995).

3 Provatas A and Matisons JG, Trends Polym Sci 5:327 (1997).

4 Loy DA and Shea KJ, Chem Rev 95:1431 (1995).

5 Lichtenhan J, Silsesquioxane-based polymers, in Polymeric Materials Encyclopedia, vol. 10, ed. by Salmone JC. CRC Press, New York, pp 7768-7777 (1996).

6 Laine RM, f Mater Chem 15:3725 (2005).

7 Gilman JW, Schlitzere DS and Lichtenhan JD, $\mathcal{f}$ Appl Poylm Sci 60:591 (1996).

8 Lichtenhan JD, Gilman JW and Feher FJ, US Patent 5484867 (1997)

9 Gonzalez RI, Phillips SH and Hoflund GB, $\mathcal{F}$ Spacecraft Rockets 37:463 (2000)

10 Phillips SH, Haddad TS and Tomczak SJ, Curr Opin Solid State Mater Sci 8:21 (2004).

11 Brunsvold AL, Minton TK, Gouzman I, Grossman E and Gonzalez RI, High Perform Polym 16:303 (2004).

12 Brunsvold AL, Minton TK, Gouzman I, Grossman E and Gonzalez RI, An investigation of the resistance of POSS polyimide to atomic oxygen attack, in Proc 9th Int Symp on Mater Space Environment, Noordwijk, The Netherlands, 16-20 June (2003).

13 Waddon AJ and Coughlin EB, Chem Mater 15:4555 (2003).

14 Gromilov SA, Basova TV, Emel'yanov DYu, Kuzmin AV and Prokhorova SA, $\mathcal{F}$ Struct Chem 45:471 (2004).

15 Feher FJ, Newman DA and Walzer JF, $\mathcal{f}$ Am Chem Soc 111:1741 (1989).

16 Feher FJ, Budzichowski TA, Blanski RL, Weller KJ and Ziller JW, Organometallics 10:2526 (1991).

17 Maschmeyer T, Klunduk MC, Martin CM, Shephard DS, Johnson BFG and Thomas JM, Chem Commun 19:1847 (1997).

18 Feher FJ and Blanski RL, $\mathcal{f}$ Am Chem Soc 114:5886 (1992).

19 Feher FJ, Soulivong D, Eklud AG and Wyndham KD, Chem Commun 13:1185 (1997).

20 Severn JR, Duchateau R, van Santen RA, Ellis DD and Spek AL, Organometallics 21:4 (2002)

21 Duchateau R, Abbenhuis HCL, van Santen RA, Meetsma A, Thiele SK-H and van Tol MFH, Organometallics 17:5222 (1998).

22 Maxim N, Magusin PCMM, Kooyman PJ, van Wolput JHMC, van Santen RA and Abbenhuis HCL, F Phys Chem B 106:2203 (2002).

23 Bonhomme C, Toledano P, Maquet J, Livage J and BonhommeCoury L, f Chem Soc Dalton Trans 9:1617 (1997).

24 Bassindale AR, Pourny M, Taylor PG, Hursthouse MB and Light ME, Angew Chem Int Ed 42:3488 (2003).

25 Bassindale AR, Parker DJ, Pourny M, Taylor PG, Horton PN and Hursthouse MB, Organometallics 23:4400 (2004).

26 Asuncion MZ, Hasegawa I, Kampf JW and Laine RM, f Mater Chem 15:2114 (2005).

27 Tamaki R, Tanaka Y, Asuncion MZ, Choi J and Laine RM, $\mathcal{J}$ Am Chem Soc 123:12416 (2001).

28 Tamaki R, Choi J and Laine RM, Chem Mater 15:793 (2003).

29 Choi J, Tamaki R, Kim SG and Laine RM, Chem Mater 15:3365 (2003).

30 Choi J, Kim SG and Laine RM, Macromolecules 37:99 (2004).

31 Laine RM, Choi J and Lee I, Adv Mater 13:800 (2001).

32 Choi J, Harcup J, Yee AF, Zhu Q and Laine RM, f Am Chem Soc 123:11420 (2001).

33 Choi J, Yee AF and Laine RM, Macromolecules 36:5666 (2003).

34 Choi J, Yee AF and Laine RM, Macromolecules 37:3267 (2004).

35 Sulaiman S, Brick CM, De Sana CM, Katzenstein JM, Laine RM and Basheer RA, Macromolecules 39:5167 (2006). 
36 Drzal LT, Rich MJ, Koenig MF and Lloyd PF, f Adhesion 16:133 (1983).

37 Matthews FL and Rawlings RD, Composites Materials: Engineering and Science. Chapman \& Hall, London, p. 14 (1994).

38 Jackson GV and Orton ML, in Particulate-filled Polymer Composites, ed. by Rothon R. Longman Scientific \& Technical, Harlow, UK, p. 317 (1995).

39 Demjen Z, Pukanszky B and Nagy J, Composites A 29:323 (1998).

40 Leu C-M, Chang Y-T and Wei K-H, Chem Mater 15:3721 (2003).

41 Huang J-C, He C-B, Xiao Y, Yi Mya K, Dai J and Siow YP, Polymer 44:4491 (2003).

42 Zhang C, Babonneau F, Bonhomme C, Laine RM, Soles CL, Hristov HA, et al, f Am Chem Soc 120:8380 (1998).

43 Laub RJ, Finkelmann H, Apfel MA, Janini GM, Luhmann BH, Price A, et al, Anal Chem 57:651 (1985).

44 Hasegawa I, Sakka S, Sugahara Y, Kuroda K and Kato C, Chem Commun 208 (1989).

45 Hasegawa I and Sakka S, Chem Lett 1319 (1988).

46 Sellinger A and Laine RM, Chem Mater 8:1592 (1996).

47 Bartsch M, Bornhauser P, Burgy H and Calzaferri G, Spectrochim Acta A 47:1627 (1991).

48 Marcolli C and Calzaferri G, $\mathcal{F}$ Phys Chem B 101:4925 (1997).

49 Marcolli C, Laine P, Buhler R, Calzaferri G and Tomkinson J, f Phys Chem B 101:1171 (1997).

50 Auner N, Ziemer N, Herrschaft B, Ziche B, John P and Weis J, Eur F Inorg Chem 1087 (1999).

51 Lynch W, Handbook of Silicone Rubber Fabrication. Van Nostrand Reinhold, New York (1978).

52 For example, Kim SM, Yoon DY, Nguyen CV, Han J and Jaffe RL, Mater Res Soc Symp Proc 511:39 (1998).

\section{APPENDIX A}

\section{Detailed studies of AIBN curing}

DTA/TGA of AIBN-initiated self-curing shows a decrease in air stability, from $c a 400^{\circ} \mathrm{C}$ for TCHS to ca $300^{\circ} \mathrm{C}$ (Fig. A1). Large exotherms are seen in the DTA trace centered at 335 and $480^{\circ} \mathrm{C}$. Indeed, the exotherm at $335^{\circ} \mathrm{C}$ is so great that the temperature recorded by the thermocouple is greater than the furnace temperature as witnessed by the slight drop in temperature below $80 \mathrm{wt} \%$. The ceramic yield for the polymer is $65.5 \mathrm{wt} \%$, in good agreement with the ceramic yield of TCHS monomer (65.7 wt \%). DTATGA of the polymer run in nitrogen (Fig. A2) shows a gradual mass loss starting at $c a 130^{\circ} \mathrm{C}$, which evolves into a much steeper mass loss at $c a 400^{\circ} \mathrm{C}$ to give a ceramic yield of $61.2 \%$. This is slightly lower than expected and indicates some sublimation, suggesting incomplete curing, as expected from the tacky sample interior.

The DSC trace (not shown) does not show any peaks, which has important implications because it indicates that segmental motions that would account for $T_{\mathrm{g}}$ in typical organic polymers are not possible in cured TCHS. Thus, when the ethylcyclohexylepoxide (OC) cube derivative is reacted with diaminodiphenyl methane to form single tethers joining two cube vertices, $T_{\mathrm{g}}$ values are seen at $c a 150^{\circ} \mathrm{C}$. Clearly, the absence of $T_{\mathrm{g}}$ in these studies indicates that segments of only 5 or 6 atoms are restrained from moving. Alternatively, they occur at below room temperature. These results contrast with our epoxy resin studies. ${ }^{18-21}$

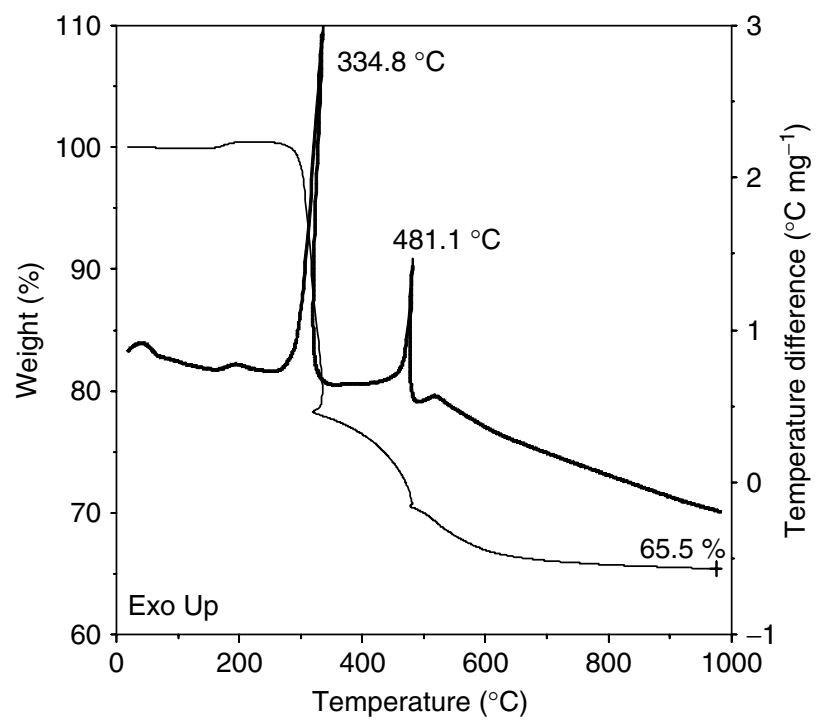

Figure A1. TGA/DTA in air of TCHS cured at $230^{\circ} \mathrm{C} / 8 \mathrm{~h}$; ramp rate $=10^{\circ} \mathrm{C} \mathrm{min}^{-1}$.

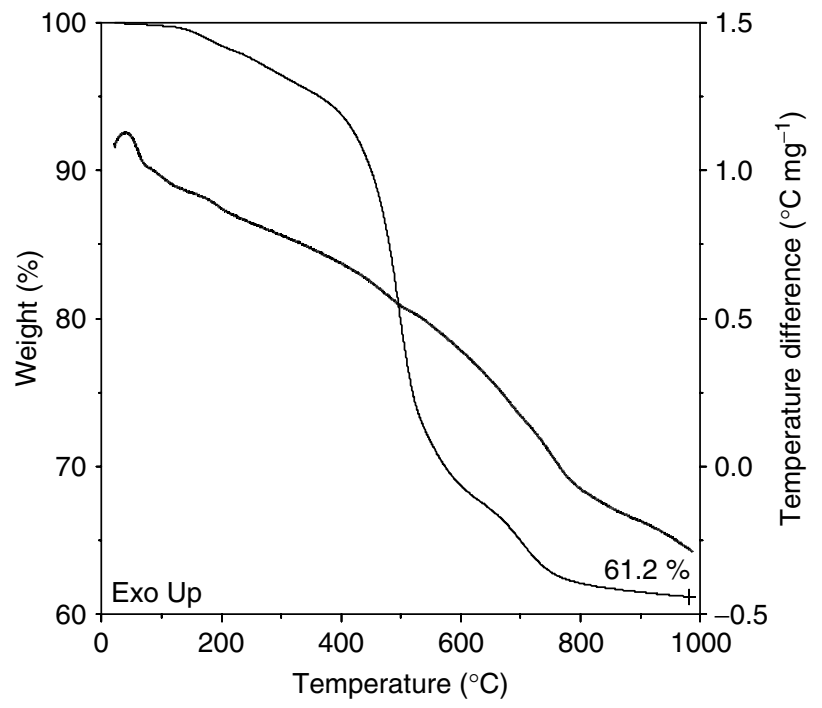

Figure A2. TGA/DTA in nitrogen of TCHS cured at $230^{\circ} \mathrm{C} / 8 \mathrm{~h}$; ramp rate $=10^{\circ} \mathrm{C} \mathrm{min}^{-1}$.

\section{Reaction of OCHS with PDMS}

OCHS was successfully cured with hydrido-endcapped PDMS (molecular weight $c a$ 400) mixed in a 1:1.25 molar ratio $(1.0 \mathrm{~g}: 0.26 \mathrm{~g})$ with $0.1 \mathrm{~mL}$ of $\mathrm{Pt}(\mathrm{dcp})$. This produced a clear, smooth and flexible solid after curing at $200^{\circ} \mathrm{C} / 5 \mathrm{~h}$ in a sealed, nitrogen-purged vacuum oven. The same experiment was run without the $\mathrm{Pt}(\mathrm{dcp})$ catalyst. After $200^{\circ} \mathrm{C} / 10 \mathrm{~h}$ the sample appeared tacky and incompletely cured.

Attempts to make tensile specimens of OCHS cured with PDMS and $0.2 \mathrm{~mL} \mathrm{Pt(dcp)} \mathrm{using} \mathrm{the} \mathrm{same}$ method as for self-cured TCHS were unsuccessful. After $200^{\circ} \mathrm{C} / 8 \mathrm{~h}$ the sample remained very tacky with many bubbles. These bubbles probably form from release of $\mathrm{H}_{2}$ during curing.

FTIR analysis (Table 3) of the catalytically cured sample of OCHS and PDMS shows residual $\nu \mathrm{C}-\mathrm{H}_{\text {alkene }}\left(3023 \mathrm{~cm}^{-1}\right)$ and $\nu \mathrm{C}=\mathrm{C} \quad\left(1652 \mathrm{~cm}^{-1}\right)$ 
peaks without a corresponding $\nu \mathrm{Si}-\mathrm{H}$ peak. The $\nu \mathrm{C}-\mathrm{H}_{\text {alkane }} \quad\left(2917 \mathrm{~cm}^{-1}\right): \nu \mathrm{C}-\mathrm{H}_{\text {alkene }} \quad\left(3023 \mathrm{~cm}^{-1}\right)$ : $\nu \mathrm{Si}-\mathrm{H}: \nu \mathrm{C}=\mathrm{C}\left(1652 \mathrm{~cm}^{-1}\right)$ are in a 1:0.38:0.00:0.26 ratio. Vinyl group peaks are expected to remain because a molar ratio of 1:1.25 (OCHS:PDMS) was used. This means that there are 8 cyclohexenyl sites per $2.5 \mathrm{Si}-\mathrm{H}$ sites. Assuming that the $\mathrm{Si}-\mathrm{H}$ groups of PDMS react fully, ca 6 cyclohexenyl sites should remain on OCHS. The decrease in vinyl group intensity along with the absence of $v \mathrm{Si}-\mathrm{H}$ indicates that crosslinking proceeds via the same mechanism as for self-cured TCHS.

The same OCHS:PDMS molar ratio was also reacted with $5 \mathrm{~mol} \% \mathrm{AIBN}$, curing at $200^{\circ} \mathrm{C} / 6 \mathrm{~h}$. The resulting product was opaque and quite brittle. FTIR analysis of this sample showed the same peaks as for the platinum-catalyzed reaction (Table 3), indicating that crosslinking does occur, unfortunately resulting in undesirable properties. The ratio of $\nu \mathrm{C}-\mathrm{H}_{\text {alkane }}\left(2910 \mathrm{~cm}^{-1}\right): \nu \mathrm{C}-\mathrm{H}_{\text {alkene }}\left(3023 \mathrm{~cm}^{-1}\right)$ : $v \mathrm{Si}-\mathrm{H}: \nu \mathrm{C}=\mathrm{C}\left(1652 \mathrm{~cm}^{-1}\right)$ is $1: 0.46: 0: 0.22$.

DTA/TGA in air (Fig. A3) shows a slight mass loss at $c a 100^{\circ} \mathrm{C}$, and then a much steeper mass loss at $c a 300^{\circ} \mathrm{C}$. The ceramic yield is $52.3 \mathrm{wt} \%$ versus $59.2 \%$ theory, and the DTA trace shows exotherms centered at 373 and $525^{\circ} \mathrm{C}$. In nitrogen (Fig. A4), a slight mass loss is again seen beginning at $c a 100^{\circ} \mathrm{C}$, and then a much steeper mass loss at $c a 400^{\circ} \mathrm{C}$ with a ceramic yield of $49.7 \%$. The DTA trace does not show any exotherms. The above interpretations can also be made as to the thermal decomposition behavior of these materials. The overall poorer thermal stability of this material compared with the above materials suggests that the PDMS linker is the component that degrades first.

\section{Reaction of OCHS with TMDS}

Attempts were made to react OCHS with TMDS in a 1:4 molar ratio, catalyzed by $\mathrm{Pt}(\mathrm{dcp})$. After heating in a sealed vacuum oven at $200^{\circ} \mathrm{C} / 5 \mathrm{~h}$, a transparent, brittle solid was produced.

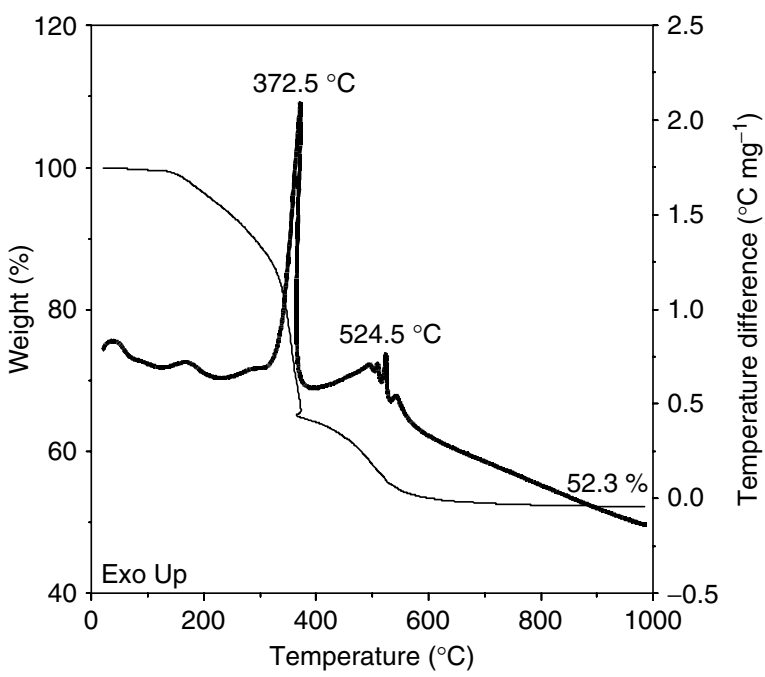

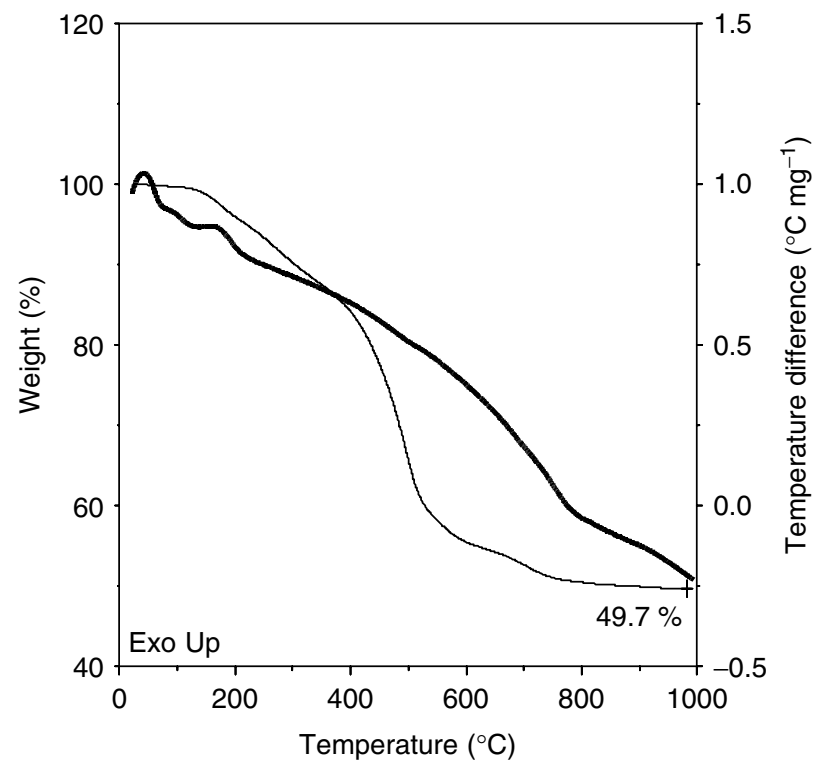

Figure A4. TGA/DTA of OCHS:PDMS copolymer in nitrogen.

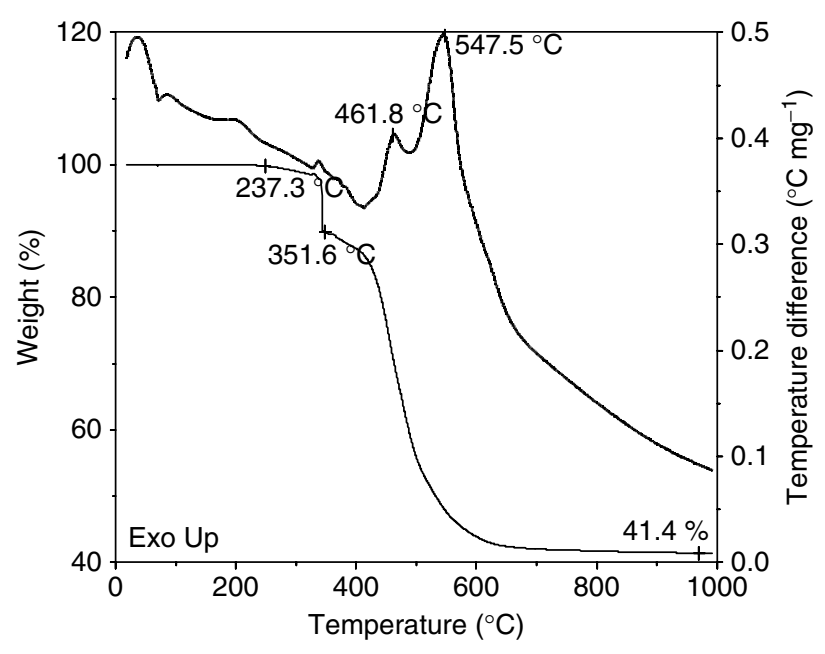

Figure A5. TGA/DTA of OCHS:TMDS copolymer in air.

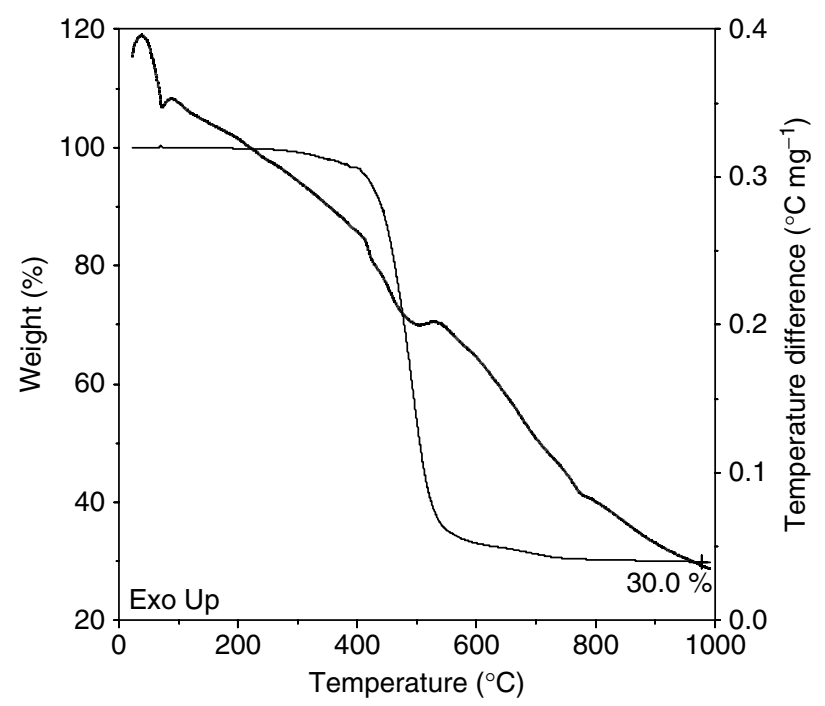

Figure A6. TGA/DTA of OCHS:TMDS copolymer in nitrogen.

Figure A3. TGA/DTA of OCHS:PDMS copolymer in air. 
FTIR analysis (Table 3) continues to show $v \mathrm{C}-\mathrm{H}_{\text {alkene }}\left(3023 \mathrm{~cm}^{-1}\right)$ and $v \mathrm{C}=\mathrm{C} \quad\left(1652 \mathrm{~cm}^{-1}\right)$ peaks, whereas the $v \mathrm{Si}-\mathrm{H}$ peak is absent. Theoretically, there is a $1: 1$ ratio of cyclohexenyl: $\mathrm{Si}-\mathrm{H}$ groups. However, because TMDS is a volatile compound and the curing process involves heating in a vacuum oven, some TMDS is likely to evaporate, resulting in excess cyclohexenyl units, explaining the presence of $v \mathrm{C}-\mathrm{H}_{\text {alkene }}$ in the FTIR spectrum after curing. The $\nu \mathrm{C}-\mathrm{H}_{\text {alkane }} \quad\left(2917 \mathrm{~cm}^{-1}\right): \nu \mathrm{C}-\mathrm{H}_{\text {alkene }} \quad\left(3023 \mathrm{~cm}^{-1}\right)$ : $\nu \mathrm{Si}-\mathrm{H}: \nu \mathrm{C}=\mathrm{C}\left(1652 \mathrm{~cm}^{-1}\right)$ band ratio was 1:0.60:0: 0.22 .

The same reaction was run with $5 \mathrm{~mol} \%$ AIBN, and cured at $200^{\circ} \mathrm{C} / 6 \mathrm{~h}$. The product was an opaque, brittle solid. FTIR analysis shows peaks nearly identical to those in spectra from the platinum-catalyzed reaction, indicating that crosslinking also occurs in the presence of AIBN. The $\nu \mathrm{C}-\mathrm{H}_{\text {alkane }}\left(2910 \mathrm{~cm}^{-1}\right): \nu \mathrm{C}-\mathrm{H}_{\text {alkene }} \quad\left(3023 \mathrm{~cm}^{-1}\right)$ : $v \mathrm{C}=\mathrm{C}\left(1652 \mathrm{~cm}^{-1}\right)$ band ratio is $1: 0.51: 0.27$.
The TGA trace in air (Fig. A5) shows a mass loss of ca $12 \%$ from 240 to $350^{\circ} \mathrm{C}$ likely due to dangling siloxane units that have not successfully crosslinked. A steep mass loss is then seen above $350{ }^{\circ} \mathrm{C}$ with a final ceramic yield of $41.4 \%$ versus $45.4 \%$ theory. Two exotherms are seen in the DTA trace run in air. The first has an onset at $430^{\circ} \mathrm{C}$, and a maximum at $460{ }^{\circ} \mathrm{C}$ over a range of $c a 60^{\circ} \mathrm{C}$. The second has an onset at $520^{\circ} \mathrm{C}$, and a maximum at $550^{\circ} \mathrm{C}$ over a range of $160^{\circ} \mathrm{C}$. Both are ascribed to decomposition of the copolymer.

The TGA run in nitrogen (Fig. A6) shows thermal stability up to $c a 400^{\circ} \mathrm{C}$ with a ceramic yield of $30.0 \%$. No exotherms are seen in the DTA trace run in nitrogen as expected. The TGA curve seems to be very similar to that of the thermally cured TCHS cube suggesting that short PDMS segments do not affect the overall thermal stability. 